\title{
Intergroup cannibalism in the European Early Pleistocene: The range expansion and imbalance of power hypotheses
}

\author{
Palmira Saladiée ${ }^{\mathrm{a}, \mathrm{b}, \mathrm{c}, *}$, Rosa Huguet ${ }^{\mathrm{a}, \mathrm{b}}$, Antonio Rodríguez-Hidalgo ${ }^{\mathrm{a}, \mathrm{b}, \mathrm{d}}$, Isabel Cáceres ${ }^{\mathrm{a}, \mathrm{b}}$, \\ Montserrat Esteban-Nadal a, , Juan Luis Arsuaga e,f, José María Bermúdez de Castro ${ }^{\mathrm{g}}$, \\ Eudald Carbonell ${ }^{\mathrm{a}, \mathrm{b}, \mathrm{h}}$
}

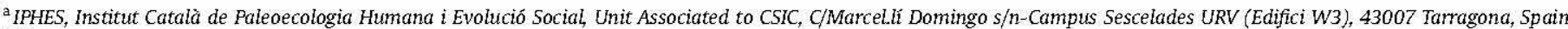

${ }^{\mathrm{b}}$ Ârea de Prehistoria, Universitat Rovira i Virgili (URV), Avinguda de Catalunya 35, 43002 Tarragona, Spain

${ }^{\complement} G Q P-C G$, Grupo Quatemário e Pré-História do Centro de Geociências (uIED 73 - FCT), Portugal

${ }^{\mathrm{d}}$ Equipo Primeros Pobladores de Extremadura, Casa de la Cultura Rodríguez Moñino, Avda. Cervantes s/n., 10003 Cáceres, Spain

'Departamento de Paleontología, Facultad de Ciencias Geológicas, Universidad Complutense de Madrid, 28040 Madrid, Spain

${ }^{6}$ Centro de Investigación (UCM-ISCII) de Evolución y Comportamiento Humanos, C/Sinesio Delgado 4, Pabellón 14, 28029 Madrid, Spain

${ }^{g}$ Centro Nacional de Investigación sobre Evolución Humana (CENIEH), Paseo Sierra de Atapuerca, s/n, 09002 Burgos, Spain

${ }^{\mathrm{h}}$ Institute of Vertebrate Paleontology and Paleoanthropology of Beijing (IVPP), People's Republic of China

\section{Keywords:}

Homo antecessor

Taphonomy

Chimpanzees

Nutritional cannibalism

Spain

\begin{abstract}
A B S T R A C T
In this paper, we compare cannibalism in chimpanzees, modern humans, and in archaeological cases with cannibalism inferred from evidence from the Early Pleistocene assemblage of level TD6 of Gran Dolina (Sierra de Atapuerca, Spain). The cannibalism documented in level TD6 mainly involves the consumption of infants and other immature individuals. The human induced modifications on Homo antecessor and deer remains suggest that butchering processes were similar for both taxa, and the remains were discarded on the living floor in the same way. This finding implies that a group of hominins that used the Gran Dolina cave periodically hunted and consumed individuals from another group. However, the age distribution of the cannibalized hominins in the TD6 assemblage is not consistent with that from other cases of exo-cannibalism by human/hominin groups. Instead, it is similar to the age profiles seen in cannibalism associated with intergroup aggression in chimpanzees. For this reason, we use an analogy with chimpanzees to propose that the TD6 hominins mounted low-risk attacks on members of other groups to defend access to resources within their own territories and to try and expand their territories at the expense of neighboring groups.
\end{abstract}

\section{Introduction}

The cannibalism that occurred in Gran Dolina's level TD6 (Sierra de Atapuerca, Burgos, Spain) has been dated to over 800 thousand years ago (ka). The current hypothesis to explain the cannibalism identified at TD6 during the Early Pleistocene is that a group of hominins periodically hunted individuals from another group, focusing mainly on younger or more defenseless individuals, in a kind of exo-cannibalism scenario (Carbonell et al., 2010). In this paper, we review cases of cannibalism among chimpanzees and modern humans as well as those documented in some

\footnotetext{
* Corresponding author.

E-mail addresses: psaladie@iphes.cat (P. Saladié), rhuguet@iphes.cat (R. Huguet), arodriguez@iphes.cat (A. Rodríguez-Hidalgo), icaceres@iphes.cat (I. Cáceres), mesteban@iphes.cat (M. Esteban-Nadal), jlarsuaga@isciii.es (J.L. Arsuaga), jm. ber@ cenieh.es (J.M. Bermûdez de Castro), ecarbonell@iphes.cat (E. Carbonell).
}

archaeological settings, and explore the hypotheses proposed for the behavior in each case. We also present an empirical taphonomic study of the hominin and deer bone assemblages from TD6 and look into the relationships between the age distribution of the individuals from TD6, other cases of cannibalism, and cannibalism in chimpanzees. We compare the available data with the results from TD6 and propose new hypotheses concerning this case in particular and human cannibalism in general.

The use of actualistic analogies as the basis for hypotheses plays a key role in any attempt to understand archaeological evidence. Comparative research carried out among communities of modern hunter-gatherers and on non-human species helps to inform our interpretations of zooarchaeological assemblages.

The cultural and non-cultural causes and effects of different processes on the formation of zooarchaeological assemblages tend to be regular, because specific formation processes are determined by specific causal variables, and the effects of certain processes lead 
to the regular and foreseeable modifications of faunal remains (Schiffer, 1987). The study of prehistoric cannibalism has two different but related objectives: to determine whether skeletal remains truly show evidence of cannibalism in specific cases, and to determine the cause of verified cases. Cannibalism is identified in archaeological assemblages through the documentation of cultural modifications that are typically associated with the practice, like the presence of cut marks on hominin bones, signs of intentional breakage and the thermo-alterations of bones (Turner II, 1983; Villa et al., 1986; White, 1992; Turner II and Turner, 1992, 1999; Boulestin, 1999; Fernández-Jalvo et al., 1999; Hurlbut, 2000; Rosas et al., 2006; Cáceres et al., 2007). The similarities between the signs of cannibalism and the effects of the butchering of other animals allow cannibalism events to be differentiated from damage due to mutilations, injuries, sacrifices, funerary rituals, or other causes (White, 1986; Hurlbut, 2000; Pickering et al., 2000). Modifications found on remains and the contexts in which they are found enable us to identify the actions to which the remains were subjected, but not always the causes of those actions. It is therefore important to proceed with caution before reaching any firm conclusions, as cannibalism is not necessarily correlated with any particular postmortem treatment of the human body (Rautman and Fenton, 2005).

Human cannibalism in archaeological contexts is identified by means of zooarchaeological and taphonomic criteria. Turner II (1983) and Turner II and Turner (1999) present different indicators to establish the existence of cannibalism, including: 1) the full or almost full disarticulation of the skeleton, 2) a high degree anthropogenic bone breakage, 3) high frequency of cut marks related to defleshing, 4) other modifications associated with cooking the remains.

The causes of human cannibalism have been cataloged, described and classified in very different ways. The practice has been categorized as nutritional or pleasure cannibalism, self-cannibalism, survival cannibalism, warfare cannibalism and mortuary cannibalism. These are further classified as either exo- or endocannibalism, depending on the origin of the people consumed (Table 1). All of these distinctions attempt to discover why humans/ hominins have been cannibals, under what circumstances and in what contexts they have engaged in the practice, and the relationship between the consumers and consumed. The study of ethnographic, ethno-historical and historical cases has revealed that it is a highly complex form of behavior, always surrounded by symbolism, rituals or emotions (compassion, respect, love, violence, contempt, hate, etc.) (Sanday, 1986; Conklin, 1995, 2001; Goldman, 1999; Kantner, 1999; Pickering, 1999; Viláça, 2000; Fausto, 2007), with no single, uniform explanation. We can use ethnographically or historically documented cases to formulate causal hypotheses, but testing these with Pleistocene assemblages is difficult, especially given the limitations of analogies between modern humans and extinct hominins, who had very different social and subsistence systems. Historical or sub-modern cannibalism has taken place in structured societies within contexts of great social and religious complexity (Sanday, 1986). The ontological system of early hominins, if one even existed, is totally unknown to us, which makes drawing analogies based only on the behavior of modern humans a risky undertaking.

Comparative research with chimpanzees provides another line of inquiry into the behavior of early hominins. Chimpanzees have provided insights into the evolution of hominin diets and social relationships, and their behavior is relevant to understanding the evolution of intra- and intergroup violence in humans (e.g., Teleki, 1973; Goodall, 1979, 1986; Nishida et al., 1979; Boesch, 1994; Stanford, 1995, 1996, 1998, 2001; Backwell and d'Errico, 2001; Mitani and Watts, 2001; Boesch et al., 2002; Fruth and Hohmann, 2002; Wrangham et al., 2006; Mitani et al., 2010; Wilson et al., 2012). Lethal intergroup violence is well documented in chimpanzees, and in many cases infanticide has been followed by the consumption of the victims (Goodall, 1977, 1979, 1986; Norikoshi, 1982; Stanford, 1995; Arcadi and Wrangham, 1999; NewtonFisher, 1999; Wrangham, 1999; Watts and Mitani, 2000; Watts et al., 2002, 2006; Wilson et al., 2004; Wrangham et al., 2006; Sherrow and Amsler, 2007).

\section{Violence and cannibalism in chimpanzees}

Both intra-community and inter-community violence is a common occurrence in chimpanzees, and males are the main perpetrators (e.g., Goodall, 1977, 1986; Nishida et al., 1979; Nishida and Kawanaka, 1985; Takahata, 1985; Nishida, 1994; Arcadi and Wrangham, 1999; Newton-Fisher, 1999; Wrangham, 1999; Watts and Mitani, 2000; Watts et al., 2002, 2006; Wilson et al., 2004; Wrangham et al., 2006; Sherrow and Amsler, 2007). Relationships between communities are hostile and encounters near community boundaries can involve serious, potentially lethal aggression. Encounters occur more frequently when an abundant supply of food attracts groups from both sides of a territorial boundary (Wilson et al., 2012). Lethal aggression sometimes occurs in the form of infanticide. Female chimpanzees often travel alone with their young or in small groups of females with their offspring, which makes them more vulnerable to the attacks of extracommunity males (Goodall, 1986; Sherrow and Amsler, 2007). However, in most documented cases, the attackers generally only

Table 1

Classification of human cannibalism.

\begin{tabular}{|c|c|c|}
\hline Type of classification & Categories & Particularities \\
\hline $\begin{array}{l}\text { Classification by the origin of } \\
\text { the consumed individuals }\end{array}$ & $\begin{array}{l}\text { Exo-cannibalism } \\
\text { Endo-cannibalism }\end{array}$ & $\begin{array}{l}\text { - Consumption of outsiders. } \\
\text { - Human remains are treated the same way as the remains of other animals. } \\
\text { - Consumption of individuals from the same group. } \\
\text { - It can be caused for reasons of respect for the deceased, after ritual sacrifices or in } \\
\text { contexts of social and political control. } \\
\text { - Ritual treatment of remains. }\end{array}$ \\
\hline \multirow[t]{4}{*}{$\begin{array}{l}\text { Classification by the } \\
\text { purpose of the consumption }\end{array}$} & Mortuary cannibalism & $\begin{array}{l}\text { - Consumption of individuals from the same group. } \\
\text { - Ritual treatment of remains. }\end{array}$ \\
\hline & Warfare cannibalism & $\begin{array}{l}\text { - Consumption of enemies (mainly young and adult males). } \\
\text { - Trophy body can be collected. } \\
\text { - There may be a ritual treatment of the bodies or they can be treated as rubbish. }\end{array}$ \\
\hline & Survival cannibalism & $\begin{array}{l}\text { - Consumption of weaker individuals (infants, old and sick). } \\
\text { - Moral prejudices can cause non-intensive consumption of bodies. }\end{array}$ \\
\hline & Nutritional cannibalism & $\begin{array}{l}\text { - Functional reasons (nutritional). } \\
\text { - Human remains are treated the same way as the remains of other animals. }\end{array}$ \\
\hline
\end{tabular}

The table provides the particularities of each type of cannibalism and the main taphonomic features that can be found in the assemblages. 
kill the infants and either frighten away the females or allow them to escape once they succeed in taking the infants. Infanticide among chimpanzees is often followed by cannibalism (Goodall, 1977; Norikoshi, 1982; Arcadi and Wrangham, 1999; NewtonFisher, 1999; Wilson and Wrangham, 2003; Wilson et al., 2004; Sherrow and Amsler, 2007).

Several hypotheses have been suggested to explain intercommunity attacks and infanticide (Table 2). The first of these, the sexual selection hypothesis, relates the death of the offspring with an increase in the possibility of males mating by inducing the mother of the victim to emigrate to their community to mate with males of the attacking group (Nishida et al., 1979; Arcadi and Wrangham, 1999). However, instances of infanticide rarely or never increase the reproductive success of the participating males in chimpanzees (Arcadi and Wrangham, 1999; Wilson et al., 2004; Sherrow and Amsler, 2007).

The second proposal is the rival coalition reduction hypothesis. Under this scenario, the attackers reduce the resistance of neighboring communities to coalitions so that males can eliminate future rivals (Takahata, 1985; Arcadi and Wrangham, 1999; NewtonFisher, 1999). But since both female and male infants have been targeted, there is no evidence to support the idea that males benefit from infanticide by eliminating future competitors (Arcadi and Wrangham, 1999) and this does not explain the attacks on females, as they do not play a significant part in the fighting between groups (Watts et al., 2006).

A third explanation is the resource competition/defense or range expansion hypothesis, which proposes that the attacks are made to frighten away or eliminate competitors for food resources (Goodall, 1977; Takahata, 1985; Boone, 1991; Watts and Mitani, 2000; Watts et al., 2002). The hypothesis suggests that aggression would occur in areas where food is abundant and where encounters with others are highly likely (Mitani et al., 2010; Wilson et al., 2012). For example, two infanticides (accompanied by cannibalism) recorded by Watts et al. (2002) occurred at a time and in an area with an abundance of resources. Wilson et al. (2012) also proved that chimpanzees are more likely to respond aggressively when defending abundant food sources, estrous females or young infants, which are vulnerable to infanticide attack by foreign males.

Another hypothesis that has been put forward is that an imbalance of power based on the size of territorial boundary patrols can predict the possibilities that one group will attack another (Manson and Wrangham, 1991; Wrangham, 1999; Sherrow and Amsler, 2007). If the attacking group is large, the members of that group are not usually wounded, which means that the attacks have a low cost. Taken with this, infanticides also indirectly support the range expansion hypothesis, as the victims who survive the attacks (generally the mothers) flee from the border areas between the ranges of each community (Sherrow and Amsler, 2007).

The imbalance of power hypothesis explains the conditions under which intergroup aggression occurs but not its causes or its function. The main cause of encounters between neighboring groups is the distribution and abundance of food resources. Several possible functions of attacks between neighboring groups of chimpanzees have been proposed, including gaining power and creating alliances, recruiting fertile females and acquiring greater catchment areas (Nishida et al., 1979; Wrangham, 1999; Williams et al., 2004; Boesch, 2009; Mitani et al., 2010; Wilson et al., 2012). These three functions are interrelated, as the acquisition of territory provides greater access to food, mates and fertile females (Wilson et al., 2012). From this perspective, the best explanation for intergroup aggression and in turn, infanticide, is the range expansion hypothesis and the defense of food resources. Whether or not encounters result in an aggressive response depends on whether the attackers have greater numerical strength.

Intragroup infanticide and cannibalism has also been documented on several occasions (Goodall, 1977, 1986; Norikoshi, 1982; Nishida and Kawanaka, 1985; Nishida, 1994; Wrangham, 1999; Wrangham et al., 2006). In these cases, the chimpanzees responsible for the deaths are also generally adult and young adult males (Norikoshi, 1982). However, females are occasionally as aggressive as males in two contexts: aggression toward immigrating females and aggression toward females of the same community when they have just given birth (Pusey et al., 2008). For example, Goodall (1977) observed a case in which a female and her daughter killed and ate infants from their own group on three separate occasions.

The distinguishing characteristics of intragroup cannibalism are that the victims are between 0.5 and three months old and that, after death, the babies are consumed and their meat is shared among a number of individuals, which may include other females (Nishida and Kawanaka, 1985).

Table 2

Features of inter- and intragroup violence in communities of chimpanzees and hypotheses about its causes.

Inter-community violence (Goodall, 1977, 1986; Nishida et al., 1979;

Takahata, 1985; Newton-Fisher, 1999; Wrangham, 1999; Watts and

Mitani, 2000; Watts et al., 2002, 2006; Wilson et al., 2004;

Wrangham et al., 2006; Sherrow and Amsler, 2007)

\section{Properties}

Aggressors are mainly young and adult males.

Victims are of neighboring communities.

Attacks occur in border areas of overlapping communities.

Victims are of both sexes and different ages, but mainly are attacked extra-community females, killing her infants.

Infanticide is accompanied by cannibalism.

The intra-community females can participate in the consumption and the meat is shared.

Hypothesis

The sexual selection hypothesis (Nishida et al., 1979; Arcadi and Wrangham, 1999).

The rival coalition reduction hypothesis (Arcadi and Wrangham, 1999; Newton-Fisher, 1999).

The resource competition or range expansion hypothesis (Watts and Mitani, 2000; Watts et al., 2002; Sherrow and Amsler, 2007).

The imbalance of power hypothesis (Manson and Wrangham, 1991; Sherrow and Amsler, 2007).
Intra-community violence (Goodall, 1977, 1986; Nishida and Kawanaka, 1985; Nishida, 1994; Wrangham, 1999; Wrangham et al., 2006)

The 'killers' are mainly males, but there have been cases of females. Infanticide is accompanied by cannibalism (infants between 0.5 and three months of age).

The females can participate in the consumption and the meat is shared.

'Within-community dominance drive' hypothesis (Goodall, 1986; Nishida, 1994; Wrangham, 1999).

Extension of between-group male cannibalism (Nishida and Kawanaka, 1985). 
To explain acts of aggression and violence among individuals of the same group, the within-community dominance drive hypothesis has been proposed, which states that aggression patterns occur within dominance hierarchies (Wrangham, 1999). This would explain cases where subordinates attack the dominant individuals if they show any sign of weakness (Norikoshi, 1982).

One observation that has been made in cases of infanticide is that in some cases, mothers were recent immigrants, and therefore within-community cannibalism could be an extension of between-group cannibalism (Norikoshi, 1982). In addition, Norikoshi (1982) also observes later sexual exchanges between the victim's mother and some of the males who took part in the cannibalism episode.

Of all the hypotheses that have been reviewed, only the sexual selection hypothesis gives a specific explanation for infanticide, and none of them provide any insight into why the attackers go on to consume their victims. In fact, cannibalism may be driven by purely nutritional reasons (Watts, Personal communication). Cannibalism and the capture and consumption of other mammals have certain similarities. Chimpanzees regularly hunt and eat a wide variety of other mammal species, but their most common prey is red colobus monkeys. Data on hunting and meat consumption have been collected at multiple sites (e.g., Teleki, 1973; Boesch, 1994; Stanford, 1996, 2001; Mitani and Watts, 2001; Boesch et al., 2002; Watts et al., 2002; Watts, 2008; Gomes and Boesch, 2009). The hunting tactics of different chimpanzee communities may include solitary hunting, but group hunting is more common. The males usually catch and kill the prey and share the meat with other individuals, even if they have not taken part in the hunt (Teleki, 1973; Busse, 1978; Boesch, 1994; Stanford, 1996, 1998; Mitani and Watts, 2001; Watts et al., 2002; Gilby, 2006; Gilby and Connor, 2010). This is also what occurs in most cases of infanticide and cannibalism. The manner in which chimpanzees consume red colobus monkeys and infant chimpanzees is essentially the same: both taxa are treated as food (Watts, Personal communication).

\section{Ethno-historical cannibalism}

The exploration of ethnographic sources as a means to analyze cannibalism within the context of known cultural systems can give rise to very useful information. Kantner (1999) analyzes 35 cases at different historical times, involving behavior that might cause serious perimortem damage. He concludes that cannibalism might occur (although not necessarily) in three different contexts: 1) during the preparation of the deceased, 2) during periods of famine, and 3) for purposes of war and social control.

Funerary preparation of the deceased and survival cannibalism in times of famine may share certain taphonomic characteristics, although the final deposition of the remains differs. Bodies subjected to mortuary cannibalism are typically buried without being mixed with other remains, whereas in the cases of cannibalism occurring during famine the remains are sometimes mixed with remains from other taxa. Victims of survival cannibalism are usually weak, young and old individuals (Kantner, 1999). The known historical cases of survival cannibalism occurred mostly within a limited time period and affected a small number of consumed individuals (see, for example, Rautman and Fenton, 2005).

Twenty-three of the 35 cases reviewed by Kantner (1999) occurred in contexts of inter- or intragroup violence. In some cases, certain parts of the body (hands, feet, scalp or heads) were removed as war trophies. The skeletal remains exhibit serious perimortem trauma to the limbs and skull (Kantner, 1999; Turner II and Turner, 1999; Hurlbut, 2000; Rautman and Fenton, 2005; Potter and Chuipka, 2010). The victims were usually male adults who were not subjected to special burial practices and who were buried collectively in some cases.

After analyzing 15 societies in which cannibalism has been documented, Sanday (1986) claims that the custom is articulated within an understanding of the world, life, death, re-birth and the supernatural, and in general, within the whole social, religious and cultural life of the people who practice it. One example is Conklin's study $(1995,2001)$ of funerary cannibalism among the Wari (Brazil), which can be understood as an act of compassion that honored the deceased. McCallum (1996) also describes the group cannibalism of the Pano Kaxinawá as an act of love, compassion and self-protection, which participants believe facilitates the rapid release of the deceased person's body and soul. In reality, cannibalism may be rejected in some societies as a wholly 'immoral' custom, while conversely, in other societies it may be an integral part of the cultural and/or ritual system (Sanday, 1986).

In Wari funerals, the deceased were honored by their consumption, although they were occasionally in an advanced state of putrefaction (Conklin, 1995, 2001; Viláça, 2000). The Wari also practiced exo-cannibalism associated with warfare, but for different reasons. Enemies' bodies were treated with less respect than animal carcasses. The Wari were careful not to waste the meat of animals and thus not offend their spirits. However, they abandoned and left behind large parts of their enemies' bodies, and made fun of them during the butchery and consumption processes. The ritual followed during the consumption of their enemies, according to Conklin (2001), was based on the expression of hostility and contempt. The Wari consumed their relatives in funerary rites in a very different way, and they firmly denied that they felt any hostility or aggression toward the deceased.

In fact, Vilaça (2000) claimed that the relationships between the consumers and consumed is one of predation in both exo- and endo-cannibalism. However, among the Bimin-Kuskumin (Papua New Guinea), the fact that cannibalism may occur in response to different causes means that there are different terms for each case (Sanday, 1986). Endo-cannibalism is understood as a part of the general scheme of the control of body fluids from one generation to the next. In exo-cannibalism, the victims are enemies and provide a tangible sign of the evil that is destroyed ritually in the interest of social and natural fertility. This behavior is heavily symbolically and ritually charged as it includes a great amalgam of social interests (Sanday, 1986).

\section{Archaeological cases in prehistoric Europe}

Cases of cannibalism in European prehistory have increased quantitatively since Villa et al. (1986) published their description of the assemblage from Fontbrégoua (France). The increase in the number of cases has been associated with methodological improvements that have also led to the reappraisal of some assemblages, such as those at Krapina (Croatia) and Monte Circeo (Italy), neither of which was found to yield any evidence of cannibalism (Trinkaus, 1985; Russell, 1987; White and Toth, 1991), the damage documented instead attributed to non-human agents. The Mousterian site of Engis 2 (Belgium) presents a similar case. The striations found on the skull of a juvenile hominin were interpreted as perimortem cut marks (Russell and LeMort, 1986) and reinterpreted as damage caused during the cleaning and restoration of the fossils, which ruled out any possibility that they were related to cannibalism or to preparation of the body in funerary rituals (White and Toth, 1989).

However, cannibalism has been practiced by multiple hominin species since the Early Pleistocene (Fernández-Jalvo et al., 1996; Carbonell et al., 2010). Anthropophagy among Neanderthals has 
been documented for the Moula-Guercy assemblage (France) (Defleur et al., 1999) and at Cueva del Sidrón (Spain) (Rosas et al., 2006). It has also been found among anatomically modern humans in the Upper Paleolithic (Andrews and Fernández-Jalvo, 2003), in the Mesolithic (Boulestin, 1999), Neolithic (Villa et al., 1986; Botella et al., 1997, 2000; Boulestin et al., 2009), and in the Bronze Age (Jelinek, 1957; Cáceres et al., 2007).

Table 3 provides a summary of the characteristics observed in seven archaeological assemblages where cannibalism has been identified, and in a further two where the possibility has been noted. In the seven cases of identified cannibalism, the cut marks and the anthropogenic breakage of the remains are consistent with the dismembering, defleshing, evisceration of the bodies and the extraction of the marrow from the bones. The distribution of the modifications is similar to that found in the animal bones in the assemblages whose cut marks were attributed to the butchery process. Thus, at least in most cases, cannibalism can be attributed to a functional cause (nutritional/pleasure or famine). However, at Fontbregoua and Gough's Cave, a possible ritual role of the human skulls has been suggested (Villa et al., 1986; Andrews and Fernández-Jalvo, 2003; Bello et al., 2011). At both sites, relatively whole human skulls have survived, despite a large number of cut marks, which is inconsistent with the treatment of the fauna found in the assemblages. In addition, at Fontbregoua the human skulls are more severely defleshed than the domestic and wild animals from the assemblage. Villa et al. (1986) suggest they were kept as trophies, which in turn supports the theory that this is a case of exo-cannibalism. Special treatment of skulls has also been identified in deposit 9 at the Neolithic site of Herxheim (Germany) (Boulestin et al., 2009). The skulls were fractured to remove the brain, yet the skull tops were carefully conserved and gathered together in nests. The butchery process was otherwise similar to that used on other fauna, and the long bones were fractured intensely to extract the marrow. Boulestin et al. (2009) propose several hypotheses to explain the cannibalism at Herxheim, the most satisfactory of which proposes that this was a case of warfare cannibalism, whose events took place within ritual activities.
Another case exhibiting certain peculiarities in the treatment of the skulls is Mirador Cave. The remains of six individuals were recovered from level MIR4, dated to the Bronze Age (Cáceres et al., 2007). Taphonomic analysis revealed that the individuals had been defleshed intensely and most specimens exhibited human tooth marks, evidence of boiling and intentional bone breakage. All of the skulls displayed a well-defined breakage pattern, with conchoidal scars around the entire perimeter of the skull tops and percussion marks on the temporal, parietal and occipital bones. These modifications suggest a clear functional objective to the processing of the bodies. However, the remains were clearly buried intentionally in a specific manner, with the skulls carefully arranged at the bottom of a pit and the other fragments on top of them, although the dates of some human bones and charcoal seem to indicate that the remains were buried several centuries after they had been consumed, by an individual or individuals unrelated to the cannibalism event. A review of the fauna in the same level (Saladié, 2009) found that there were no faunal remains inside the pit and that some human remains were dispersed on other parts of the surface and mixed with other archaeological material. Also, while the humans had only been boiled, the remains of other fauna showed evidence of being both roasted and boiled. The faces of the individuals in MIR4 were severely fractured, which may have been a consequence of violence and warfare cannibalism, or might simply have resulted from intense processing of the bodies and skulls to remove the brains.

At the sites that have been described, the minimum number of individuals varies between five and 13 . Adult individuals predominate, however, some of the assemblages show distinctive age profiles. At Cueva del Mirador, only one of six individuals is a child, whereas at Moula Guercy adolescents and children outnumber the adults (Defleur et al., 1999). Despite the absence of older adult individuals, this age profile would be congruent with survival cannibalism (White, 1992; Kantner, 1999), in which old, young and weak individuals are expected to be found. In the other three cases, the proportion of adults is generally similar to that of sub-adults (Villa et al., 1986; Boulestin, 1999; Andrews and Fernández-Jalvo, 2003; Boulestin et al., 2009).

Table 3

Characteristics of the different cases of cannibalism documented in European prehistory.

\begin{tabular}{|c|c|c|c|c|c|c|}
\hline Site & Period / Age & MNI & Individuals age & Butchering process & Interpretation & References \\
\hline Moula-Guercy & $\begin{array}{l}\text { Mousterian } \\
100,000-120,000 \mathrm{BP}\end{array}$ & 6 & $\begin{array}{l}2 \text { adults } \\
2 \text { adolescents } \\
2 \text { infants }\end{array}$ & $\begin{array}{l}\text { Butchering process similar } \\
\text { between hominins and animals. }\end{array}$ & $\begin{array}{l}\text { Nutritional or starvation } \\
\text { cannibalism. }\end{array}$ & Defleur et al., 1999 \\
\hline El Sidrón & $\begin{array}{l}\text { Mousterian } \\
43,129+/-129 \text { cal BP }\end{array}$ & 13 & $\begin{array}{l}4 \text { adults } \\
3 \text { adults young } \\
3 \text { adolescents } \\
2 \text { juveniles } \\
1 \text { infant }\end{array}$ & $\begin{array}{l}\text { Model consisting of the exploitation } \\
\text { of meat, marrow and brain. }\end{array}$ & $\begin{array}{l}\text { Nutritional or starvation } \\
\text { cannibalism. }\end{array}$ & $\begin{array}{l}\text { Rosas et al., 2006, 2012; } \\
\text { Lalueza-Fox et al., } 2011\end{array}$ \\
\hline Gough's Cave & Upper Paleolithic & 5 & $\begin{array}{l}2 \text { adults } \\
2 \text { adolescents } \\
1 \text { infant }\end{array}$ & $\begin{array}{l}\text { Butchering process similar } \\
\text { between humans and animals. }\end{array}$ & $\begin{array}{l}\text { Nutritional cannibalism / } \\
\text { ritual treatment of the skulls. }\end{array}$ & $\begin{array}{l}\text { Andrews and } \\
\text { Fernández-Jalvo, } \\
\text { 2003; Bello et al., } 2011\end{array}$ \\
\hline Grotte des Perrats & Mesolithic & 8 & $\begin{array}{l}5 \text { adults } \\
3 \text { immature }\end{array}$ & $\begin{array}{l}\text { Model consisting of the exploitation } \\
\text { of meat, marrow and brain. }\end{array}$ & Functional cannibalism. & Boulestin, 1999 \\
\hline Fontbrégoua & Neolithic & 6 & $\begin{array}{l}3 \text { adults } \\
2 \text { infants } \\
1 \text { of unknown age }\end{array}$ & $\begin{array}{l}\text { Butchering process similar } \\
\text { between humans and animals. }\end{array}$ & $\begin{array}{l}\text { Exo-cannibalism / nutritional } \\
\text { cannibalism / ritual treatment } \\
\text { of the skulls. }\end{array}$ & Villa et al., 1986 \\
\hline Herxheim & Neolithic & 10 & $\begin{array}{l}6 \text { adults } \\
2 \text { infants } \\
2 \text { perinatal }\end{array}$ & $\begin{array}{l}\text { Butchering process similar } \\
\text { between humans and animals. }\end{array}$ & $\begin{array}{l}\text { Possible warfare cannibalism } \\
\text { in a ritual context. }\end{array}$ & Boulestin et al., 2009 \\
\hline Cueva del Mirador & Bronze age & 6 & $\begin{array}{l}1 \text { adult old } \\
5 \text { adults } \\
1 \text { infant }\end{array}$ & $\begin{array}{l}\text { Model consisting of the exploitation } \\
\text { of meat, marrow and brain. }\end{array}$ & Nutritional cannibalism. & Câceres et al., 2007 \\
\hline Eshkaft-e Gavi & Epi-Paleolithic? & 4 & $\begin{array}{l}2 \text { adults } \\
2 \text { juveniles }\end{array}$ & $\begin{array}{l}\text { Model consisting of the exploitation } \\
\text { of meat, marrow and brain. }\end{array}$ & $\begin{array}{l}\text { Possible undetermined } \\
\text { cannibalism. }\end{array}$ & Scott and Marean, 2009 \\
\hline Castell di Guido & Late Middle Pleistocene & 2 & 2 adults & Possible cut marks and bone breakage. & $\begin{array}{l}\text { Possible but uncertain } \\
\text { anthropic use of bodies. }\end{array}$ & $\begin{array}{l}\text { Mariani-Constantiniet al., } \\
2001\end{array}$ \\
\hline
\end{tabular}




\section{The case of Early Pleistocene level TD6}

\section{The Gran Dolina site}

The oldest evidence of the practice of cannibalism among hominins comes from level TD6 at the Gran Dolina site, a cave located in the railway trench in the Sierra de Atapuerca (Burgos, Spain). Magnetic polarity has been used to date level TD6 to the Matuyama Chron (>780 ka) (Parés and Pérez-González, 1995, 1999). Combined ESR and uranium series data yield an age of somewhere between 780 and 857 ka (Falguères et al., 1999). Thermo-luminescence and infrared stimulated luminescence data provide an age of $960 \pm 120 \mathrm{ka}$ (TL) (Berger et al., 2008). Paleoclimatic and paleo-environmental studies indicate that in general, level TD6 corresponds to a period with an inter-glacial climate and vegetation similar to Mediterranean open woodlands with great potential for nutrients (García-Antón, 1998; Cuenca-Bescós et al., 1999; Burjachs, 2002; Rodríguez et al., 2011).

In 1994, hominin remains were found in this level and attributed to Homo antecessor (Bermúdez de Castro et al., 1997, 1999; Carbonell et al., 1999). The remains exhibit numerous anthropogenic modifications on their surfaces suggesting they had been processed and consumed by other hominins (Fernández-Jalvo et al., $1996,1999)$. This would make the TD6 remains the earliest known examples of cannibalism among members of the genus Homo.

Together with the hominin remains, a large number of faunal remains and over 700 lithic artifacts made of chert, quartzite, sandstone, quartz and limestone have been recovered. The lithic assemblage is attributed to Technological Mode 1 (Carbonell et al., 1999).

These hominins preyed on a wide range of species (herbivores, carnivores and $H$. antecessor) (Saladié et al., 2011). Besides $H$. antecessor, species displaying anthropogenic modifications include Eucladoceros giulii, Dama nestii vallonetensis, Cervus elaphus, cf. Bison voigtstedtensis, Equus sp., Stephanorinus etruscus, Cercopithecidae, Ursus dolinensis and Vulpes praeglacialis. Along with the zooarchaeological and sedimentological evidence, this indicates that Gran Dolina was a residential site (Bermúdez de Castro et al., 1999). All of the available data suggest that TD6 was occupied repeatedly, as the stratification of the level indicates (Bermúdez de Castro et al., 2008; Carbonell et al., 2010). Remains of $H$. antecessor with anthropogenic modifications have been found in all six layers.

\section{Methods}

We followed the analytical method developed by Saladié et al. (2011). However, this work also includes a brief description of various points that are of particular interest within the context of this study. To compare the age groups of chimpanzees, European prehistoric cannibalism and the TD6 assemblage ( $H$. antecessor and Cervidae), we performed a correspondence analysis. We distinguished three age groups: infants, juveniles and adults (see Saladié et al., 2011 for the description of the age groups).

The entire surface of all of the bones were macroscopically and microscopically examined (OPTHEC $120 \mathrm{HZ}$ magnifications), and the location, segment, portion and face of all of the anthropogenic modifications (cut marks and bone breakages) were noted.

We recognized three types of cut marks: slicing, scraping and chop marks (Shipman and Rose, 1983; Blumenschine et al., 1996). Slicing marks occur when the tool is applied with force parallel to the long axis of the tool's edge. Scraping marks occur when the edge is applied perpendicularly to the bone surface, generating multiple unidirectional striations. On many occasions, these are associated with periosteum removal, although they may also result from the removal of remains of flesh adhering to the bone
(Domínguez-Rodrigo, 2002). Finally, chop marks are the product of the application of a dynamic force (percussion) using a tool with an edge (Lyman, 2008).

Depending on their location, orientations and morphology, cut marks can be associated with particular butchery activities. To make these associations, we used the observations of Binford (1981, 1984), White (1992), Fisher (1995), Nilssen (2000) and Pobiner et al. (2008) and the observations of the IPHES team from their experience in defleshing a chimpanzee using stone tools. The actualistic studies enabled us to determine distinctive signs of skinning, dismembering and/or disarticulation, defleshing, evisceration, periosteum removal and possible tendon removal. Whenever possible, we noted the muscles, tendons or ligaments associated with the marks.

We also recorded the presence/absence and locations of percussion pits, peeling, and adhered flakes on the surface of each of the remains, following the method of Blumenschine and Selvaggio (1988).

\section{Results}

The TD6 assemblage is made up of a broad range of taxa (see Table 4), as 16 different species have been identified (Bermúdez de Castro et al., 1997; García and Arsuaga, 1999, 2001; Made, 2001; García, 2003). According to the NISP and MNI, the predominant group of remains corresponds to deer, followed by $\mathrm{H}$. antecessor (Table 3). We compared the modifications found on the hominin remains with those on small and medium-sized Cervidae remains (Dama nestii vallonetensis and C. elaphus cf. acoronatus), due to their abundance and because the adult body mass of small and mediumsized deer is similar to that of the hominins.

TD6-2 contains many remains that are not taxonomically identifiable, especially fragments of ribs and vertebrae. Therefore, to complete this assemblage we have chosen to include the remains of small and medium-sized animals that were taxonomically unidentified.

To date, $164 \mathrm{H}$. antecessor remains have been recovered from TD6. Another two possible remains (ulna and tibia fragments) are regarded as doubtful. Elements have been recovered from every part of the skeleton. Fragments of crania, maxilla, mandible and isolated teeth make up $32.3 \%$ of the assemblage and specimens from the axial skeleton (vertebrae, clavicles and ribs) are also abundant (32.3\%). The phalanges of the hands and feet are well

Table 4

Taxa identified in level TD6-2 at Gran Dolina

\begin{tabular}{lrlccccc}
\hline Taxa & NISP & MNI & Infant & Sub-adult & Adult & old \\
\hline Homo antecessor & 165 & 11 & 8 & 2 & 1 & - \\
Eucladoceros giulii & 7 & 2 & - & 1 & 1 & - \\
Dama nestii vallonetensis & 20 & 2 & - & 2 & - & - \\
Cervus elaphus cf. acoronatus & 293 & 4 & - & 1 & 2 & 1 \\
Cervidae indet. & 271 & 2 & 2 & - & - & - \\
cf. Bison voigtstedtensis & 119 & 4 & - & 1 & 2 & 1 \\
Equus (Stenonian) & 59 & 3 & - & 1 & 2 & - \\
Stephanorhinus etruscus & 45 & 2 & 1 & 1 & - & - \\
Sus scrofa & 1 & 1 & - & - & 1 & - \\
Cercopithecidae & 2 & 1 & - & - & 1 & - \\
Mammuthus sp. & 1 & 1 & 1 & - & - & - \\
Canis mosbachensis & 17 & 1 & - & 1 & - & - \\
Vulpes praeglacialis & 7 & 1 & - & 1 & - & - \\
Canidae indet. & 1 & - & - & - & - & - \\
Ursus dolinensis & 9 & 1 & - & 1 & - & - \\
Crocuta crocuta & 3 & 1 & - & 1 & - & - \\
Lynx sp. & 4 & 1 & - & 1 & - & - \\
Carnivora indet. & 15 & - & - & - & - & - \\
Total & 1039 & 38 & 12 & 14 & 10 & 2 \\
\hline
\end{tabular}

The table shows the NISP and MNI. The individuals' age of death is noted. 
represented (14.4\%). Long bones are present but rare, however, parts of both arms and legs have been found.

The assemblage of cervid remains amounts to 767 specimens, from all parts of the skeleton. 54.7\% $(n=420)$ are cranial remains, including many isolated teeth and antler fragments, $14.9 \%(n=115)$ are parts of the trunk (ribs, vertebrae and os coxae), $41.6 \%(n=319)$ are limb bones comprising mainly bone shaft fragments, and $2.9 \%$ $(n=23)$ are phalanges.

Based on the evidence from the maxillae, mandibles and teeth, a minimum number of individuals (MNI) of 11 has been established for $H$. antecessor (Bermúdez de Castro et al., 1997, 2006, 2008, 2010; Carbonell et al., 2005) (Table 4). Six were children, four of whom were younger than five years of age and two of whom were between five and nine years of age at the time of death, three were between 10 and 15 years of age, and two were young adults (see the age determining methods in Bermúdez de Castro et al., 2006, 2008, 2010). The sizes of the mandibles have led to the further identification of two male individuals and one female (Carbonell et al., 2005; Bermúdez de Castro et al., 2008).

The MNE of the cervids is 160 and the MNI is eight: two infants, three juveniles, two prime adults and one elderly adult (Table 4). The method used to determine the age of death can be consulted in Saladié et al. (2011).

A correspondence analysis (Fig. 1) was performed to compare the age distribution of the $H$. antecessor individuals with other cases of cannibalism in European prehistory and among chimpanzees versus deer from TD6. The most discriminant variable in axis 1 (eigenvalue $=75.1$ ) is the frequency of infants in the sets. This variable clearly separates $H$. antecessor and chimpanzees from the other groups, indicating a clear relationship between the two sets of analyses. Axis 2 (eigenvalue $=24.9$ ) creates two groups that seem closely associated and whose most discriminating factor is the presence of juvenile individuals in the assemblages. On the other hand, there is a clear horizontal distance between the cervid set and the $H$. antecessor set in TD6.

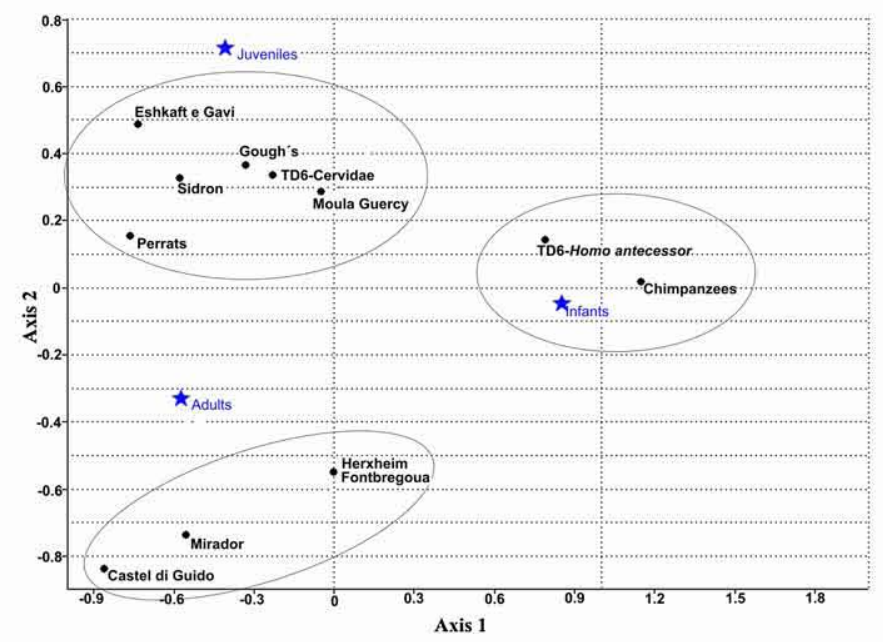

Figure 1. Multiple correspondence analysis of age distribution of the individuals from TD6-Homo antecessor and TD6-cervids, and other prehistoric European cannibalism assemblages including data from Eshkaft-e Gavi and Castell di Guido, which are possible but uncertain cases of cannibalism; data on human/hominins cases from Villa et al. (1986), Boulestin (1999), Defleur et al. (1999), Mariani-Constantini et al. (2001), Andrews and Fernández-Jalvo (2003), Cáceres et al. (2007), Boulestin et al. (2009), Scott and Marean (2009), and Lalueza-Fox et al. (2011). Data on chimpanzee cases from Suzuki (1971), Nishida et al. (1979), Takahata (1985), Newton-Fisher (1999), Watts et al. (2002), Wilson et al. (2004), and Sherrow and Amsler (2007). We get an explanation from $100 \%$ taking into account the two dimensions (eigenvalue axis $1=75.1$, eigenvalue axis $2=24.9$ ).

\section{$H$. antecessor butchering process}

Signs of anthropic activity have been seen on $41.0 \%(n=67)$ of the $H$. antecessor remains. These activities are related to the processing of soft tissues (flesh, viscera, brains, and periosteum) and the breakage of the bones to reach the marrow. Eighteen of the remains exhibited evidence of both activities. 28.7\%, representing all of the anatomical parts recovered, exhibit cut marks related to all of the activities involved in meat processing (skinning, dismembering, defleshing and evisceration) (Table 5). Slicing marks were by far the most abundant, followed by scraping marks and chop marks. Anthropogenic breakage affected 20.9\% of the assemblage $(n=35)$.

Crania and mandibles Seven cranial fragments and two mandibles display cut marks from skinning and defleshing. Evidence of skinning comprises longitudinal slicing marks found on a fragment of a frontal bone related to the removal of the scalp. Signs of defleshing are present on more bones: a fragment of the pterion region has 11 longitudinal incisions associated with cutting the musculus temporalis, and on a zygomatic fragment, seven incisions were left during the removal of the musculus masseter.

Cut marks related to defleshing are also found in the facial area. One of the maxillae displays incisions on part of the cheekbone, also associated with the removal of the musculus masseter. A second maxilla displays longitudinal and transversal incisions and scraping in the frontal alveolar zone made during the removal of the lips by cutting the musculus buccinator.

A fragment of the asterion region has nine transversal incisions caused while cutting the musculus sternocleidomastoideus during the dismemberment of the skull.

Anthropogenic breakage due to direct percussion on the cranial skeleton has been identified on seven remains. Percussion pits on the malar bone near the orbit were documented in two cases, and such pits were found near the pterion zone in one case.

Evidence of defleshing has been found on two mandibles. A left hemi-mandible displays a single incision near the oblique line of the mandibular body and a group of incisions on the ascending ramus. A second mandible displays an oblique incision on the ventral edge in the central part of the mandibular body. This mandible also displays evidence of percussion in the area below $\mathrm{M}_{2}$. Both cases are associated with cutting the musculus masseter. Shoulder and pelvic girdles Processing signs occur on three clavicles, one scapula, one sacrum and one os coxa. The butchery activity identified includes dismembering, defleshing and bone breakage.

One of the clavicles also has incisions near the acromial extremity produced during the separation of the trunk from the upper limb. All of the clavicles in this group $(n=3)$ display transversal or oblique cut marks on the mid-shaft. All of the incisions were made when cutting the musculus pectoralis major. Peeling on the acromial extremity was probably caused during the disarticulation of the scapula.

One of the scapulae exhibits incisions around the scapular neck consistent with disarticulation of the trunk and the upper limb. One sacrum has cut marks on the anterior face related to defleshing or evisceration. Marks around the edge of the acetabulum on one os coxa are evidence of separation of the trunk from the lower limb. Trunk An axis from an infant individual has three transverse incisions on the left lamina, produced during dismembering of the skull and the trunk. The skull was separated from the body at the second cervical vertebra. A thoracic vertebra exhibits four incisions on the caudal articular surface, consistent with disarticulation between the ribs and the vertebrae. Two vertebrae show slicing marks due to butchering of the musculus semispinalis capitis.

Twelve ribs present cut marks, and evisceration and defleshing have also been documented on these pieces. Evidence of defleshing 
Summary of the location, morphology and activity from which the cut marks documented on Homo antecessor specimens were performed.

\begin{tabular}{|c|c|c|c|c|c|}
\hline Segment & Element & Location & $\mathrm{Cm}-\mathrm{m}$ & Tissues/areas affected (activity) & Finality \\
\hline \multirow[t]{3}{*}{ Cranium } & Calottes & Temporal and zygomatic & S1 & $\begin{array}{l}\text { M. sternocleidomastoideus } \\
\text { Scalp }\end{array}$ & $\mathrm{Sk}+\mathrm{Df}$ \\
\hline & Maxillae & Below orbital bone & $\mathrm{Sl} / \mathrm{SC}$ & $\begin{array}{l}\text { M. masseter } \\
\text { M. buccinator }\end{array}$ & Df \\
\hline & Mandible & Below molars and ascending ramus & S1 & M. masseter & Df \\
\hline \multirow[t]{3}{*}{ Shoulder and Pelvic Girdles } & Clavicle & Shaft and ends & $\mathrm{Sl} / \mathrm{SC}$ & $\begin{array}{l}\text { M. pectoralis major } \\
\text { Coracohumeral ligament }\end{array}$ & $\mathrm{Df}+\mathrm{Da}$ \\
\hline & Scapula & Neck & S1 & Glenohumeral ligaments & $\mathrm{Dm}$ \\
\hline & Os coxae & Edge of acetabular fossa & S1 & Iliofemoral ligament & Da \\
\hline \multirow[t]{2}{*}{ Trunk } & Vertebrae & Laminae, spinous process and above articular facets & S1 & $\begin{array}{l}\text { M. semispinalis capitis } \\
\text { M. trapezius } \\
\text { Thoracolumbar fascia }\end{array}$ & $\mathrm{Df}+\mathrm{Da}$ \\
\hline & Ribs & Neck and shaft, ventral and external sides & S1 & $\begin{array}{l}\text { M. pectoralis major } \\
\text { M. transversus abdominis } \\
\text { M. obliquus externus } \\
\text { M. latissimus dorsi } \\
\text { Visceral content }\end{array}$ & $D f+D a+E v$ \\
\hline \multirow[t]{3}{*}{ Hind limb } & Humerus & Medial and distal shaft, anterior and posterior sides & S1 & $\begin{array}{l}\text { Origin of } \mathrm{m} \text {. triceps brachii medial } \\
\text { Origin of } \mathrm{m} \text {. brachialis }\end{array}$ & Df \\
\hline & Radius & Distal shaft, anterior and posterior sides & $\mathrm{Sl} / \mathrm{Sc} / \mathrm{Ch}$ & M. flexor pollicis longus & $\mathrm{Df}+\mathrm{Da}+\mathrm{Pr}$ \\
\hline & Ulna & Medial and distal shaft, posterior side & $\mathrm{Sl} / \mathrm{SC}$ & Insertion of $\mathrm{m}$. flexor digitorum profundus & $\mathrm{Df}+\mathrm{Pr}$ \\
\hline \multirow[t]{2}{*}{ Fore limb } & Femur & Proximal, medial and distal shaft, all sides & $\mathrm{Sl} / \mathrm{SC}$ & Origin of $m$. vastus intermedius & $\mathrm{Df}+\mathrm{Pr}$ \\
\hline & $\begin{array}{l}\text { Tibia } \\
\text { Fibula }\end{array}$ & $\begin{array}{l}\text { Distal side, anterior side } \\
\text { Proximal shaft, lateral side }\end{array}$ & $\begin{array}{l}\text { S1 } \\
\text { S1 }\end{array}$ & $\begin{array}{l}\text { Achilles tendon } \\
\text { Origin of } \mathrm{m} \text {. peroneus longus }\end{array}$ & Df \\
\hline \multirow[t]{2}{*}{ Hands and foot } & Metapodial & $\begin{array}{l}\text { Medial shaft, lateral side and proximal end, } \\
\text { anterior side }\end{array}$ & S1 & $\begin{array}{l}\text { M. interossei palmares and plantares } \\
\text { Tarsal ligaments }\end{array}$ & $\mathrm{Df}+\mathrm{Da}$ \\
\hline & Phalanges & $\begin{array}{l}\text { Proximal, medial and distal shaft, anterior and } \\
\text { palmar sides }\end{array}$ & S1 & Tendons of the m. flexor digitorum & Tr or df \\
\hline
\end{tabular}

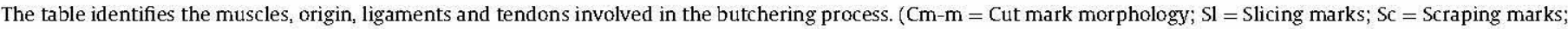
$\mathrm{Ch}=$ Chop marks; $\mathrm{Df}=$ Defleshing; $\mathrm{Sk}=$ Skinning; $\mathrm{Dm}=$ Dismembering; $\mathrm{Da}=$ Disarticulation; Ev $=$ Evisceration; $\mathrm{Pr}=\mathrm{Periosteum}$ removal; $\mathrm{Tr}=\mathrm{Tendon}$ removal).

$(n=5)$ consists of cut marks on the external face in several parts of the diaphysis. The characteristics of evisceration $(n=9)$ are similar, although in this case the oblique or transversal cut marks are on the internal face of the ribs. In two cases, scraping marks provide evidence of evisceration.

Peeling is common. Nine ribs and five vertebrae show signs of this technique. Peeling is seen on different portions of the ribs and can occasionally be associated with the disarticulation of the vertebrae. On the vertebrae, the marks are on the apophyses and articular surfaces. These could also have been produced during the consumption of these parts, by a combination of manual and oral force (Pickering and Wallis, 1997; Cáceres et al., 2007; Saladié, 2009), as they occasionally display modifications associated with tissue crushing and small depressions suggesting the anthropogenic origin of the tooth marks (Saladié, 2009; Saladié et al., in prep.).

Arms and legs of the 13 bone fragments identified as belonging to arms and legs, nine have cut marks. Additionally, this group contains another two possible $H$. antecessor remains. Cut marks resulted mainly from defleshing, although periosteum removal has also been documented.

of the three humeri, one that includes the distal mid-shaft and the epiphysis has incisions on the posterior and lateral faces of the medial part of the shaft. These incisions were caused by cutting the origin of the musculus brachialis.

Both of the $H$. antecessor radii recovered exhibit cut marks. In one of them, the shaft is almost whole. It has incisions on the medial portion of the cranial side and a chop mark on the distal portion of the posterior face, both produced by cutting the origin of the flexor pollicis longus. The second radius is represented by an almost-complete distal mid-shaft with scraping on the posterior face of the medial part of the shaft. The scraping presumably resulted from shaving the bone to deflesh it, not from its preparation for breakage.
One ulna shaft fragment shows transverse incisions on its central portion from cutting the insertion of the musculus flexor digitorum profundus. A second possible ulna shaft fragment shows scraping associated with percussion marks, apparently produced to prepare the surface for breakage.

Four fragments of femur shafts have incisions. These are on different faces and at different heights, but all are related to cutting the origin of the musculus vastus intermedius. One specimen also has scraping associated with a percussion mark, which would have facilitated bone breakage.

Finally, a tibia fragment and another possible $H$. antecessor tibia shaft display oblique incisions on their distal parts, caused by cutting the Achilles tendon for defleshing or to dismember the lower leg.

Anthropogenic breakage was found on the two radii, the two ulna fragments, two femurs and a tibia. The two radii, which belonged to sub-adult individuals, display peeling in the distal part of the shaft, although the peeling is more incipient in one of them. The remaining fragments exhibit percussion pits on the mid-shafts. There are adhered flakes on four of these fragments.

Hands and feet Cut marks were found on three metapodials and four phalanges. One metapodial has oblique incisions over the entire surface of the diaphysis. The other two have marks on the proximal part of the medial face of the diaphysis. Two phalanges have incisions in the central part of the diaphysis, one on the palmar surface and the other on the dorsal side. The other two specimens have incisions near the epiphyses. These cut marks are mainly transverse to the sagittal axis of the bone and cut the tendons of the flexor digitorum musculus. Although we do not yet understand the reason for these marks, they were produced by cutting the tendons in the hands and feet.

Anthropogenic breakage has been documented in two phalanges and a metacarpal. The other three remains display peeling at one of their ends. One phalanx also exhibits percussion 
marks. The combination of the two modifications possibly resulted from dismembering the phalanges.

\section{Cervidae butchering process}

178 cervid remains (23.2\%) exhibit cut marks ( $n=115 ; 14.9 \%)$ and/or anthropogenic breakage ( $n=77,10.0 \%)$. Fourteen remains (1.8\%) display both kinds of damage. The cut marks on cervid bones are associated with all kinds of activities involved in the processing of carcasses, as in the case of the $H$. antecessor remains. Slicing marks are the most common type of modification (Table 6).

Crania and mandibles Among the cranial remains, ten specimens exhibit cut marks, of which three are on mandibles. The position and direction of the slicing marks on four cranial fragments (occipital, nasal, maxilla and mandible) relate them to the carcass skinning process. They are arranged obliquely on the skull fragments, and were possibly generated during the separation of the skin from the bone. In the case of the occipital fragment, the incisions are longitudinal to the sagittal axis, which clearly indicates that they were made while skinning the animal and not during the dismembering of the skull from the trunk. In the case of the mandible, there are two incisions on the lower part of the ventral edge.

On one mandible, incisions on the ventral face of the ascending ramus in the area of the musculus styloglossus documents the removal of the tongue. This mandible and one other show signs of the disarticulation of the head. Both remains have incisions on the lateral face, near the mandibular condyle and in the mandibular notch, apparently produced during the separation of the mandible from the cranium.

Anthropogenic breakage has also been found in two neurocranial fragments in the form of peeling.

Shoulder and pelvic girdles Cuts have been documented on two scapulae and two os coxae that coincide with marks typical of defleshing and dismembering. One of the scapulae has a group of six oblique incisions located on the dorsal face of the scapular body. The marks were caused while filleting the musculus deltoid. Both os coxae display cut marks on the ilium, incisions on the upper face in one case and scraping on the lower face in the other. The former occurred when cutting the beginning of the musculus iliacus and the latter appears to have been caused during the removal of pieces of meat.

The transverse cuts on the neck of a scapula are evidence of the disarticulation of the humerus.

Peeling has been found on the edges of the fractures in three scapulae. These remains exhibit no other forms of modification. Trunk Cut marks were documented on 27 ribs and five vertebrae. This damage has been associated with defleshing, evisceration and dismembering.

The action of defleshing has left cut marks on the largest number of remains. On the ribs, the marks are found on different parts of the diaphysis: on the intercostal edge in one case, and on external face in the other cases. These marks are always incisions. On the vertebrae, the incisions are found on the laminae and at the

Table 6

Summary of the location, morphology and activity from which the cut marks documented on Cervidae specimens were performed.

\begin{tabular}{|c|c|c|c|c|c|}
\hline Segment & Element & Location & $\mathrm{Cm}-\mathrm{m}$ & Tissues/areas affected (activity) & Finality \\
\hline \multirow[t]{3}{*}{ Cranium } & Calottes & $\begin{array}{l}\text { Occipital and parietals } \\
\text { Nasal and neurocranial bones }\end{array}$ & S1 & Insertion of $\mathrm{m}$. semispinalis capitis & Sk \\
\hline & Maxillae & Above molars & S1 & M. buccinator & Sk \\
\hline & Mandible & Ascending ramus and notch, lateral side & S1 & $\begin{array}{l}\text { M. temporalis } \\
\text { M. styloglossus }\end{array}$ & $\mathrm{Sk}+\mathrm{Da}$ \\
\hline \multirow[t]{2}{*}{ Shoulder and Pelvic girdles } & Scapula & Neck, and dorsal and ventral surfaces & S1 & $\begin{array}{l}\text { M. deltoid } \\
\text { Glenohumeral ligaments }\end{array}$ & $\mathrm{Df}+\mathrm{Dm}$ \\
\hline & Os coxae & Inferior edge of ilium & $\mathrm{Sl} / \mathrm{Sc}$ & Origin of m. gluteus minimus & Df \\
\hline \multirow[t]{2}{*}{ Trunk } & Vertebrae & $\begin{array}{l}\text { Laminae, spinous process and above } \\
\text { articular facets }\end{array}$ & S1 & $\begin{array}{l}\text { M. trapezius } \\
\text { Thoracolumbar fascia }\end{array}$ & $\mathrm{Df}+\mathrm{Da}$ \\
\hline & Ribs & Neck and shaft, ventral and external sides & S1 & $\begin{array}{l}\text { M. pectoralis major } \\
\text { M. transversus abdominis } \\
\text { M. obliquus externus } \\
\text { M. latissimus dorsi } \\
\text { Visceral content }\end{array}$ & $\mathrm{Df}+\mathrm{Da}+\mathrm{Ev}$ \\
\hline \multirow[t]{3}{*}{ Hind limb } & Humerus & Proximal, medial and distal shaft, all sides & $\mathrm{Sl} / \mathrm{SC}$ & $\begin{array}{l}\text { M. brachialis } \\
\text { M. deltoid } \\
\text { Origin of m. triceps brachii medial }\end{array}$ & $\mathrm{Df}+\mathrm{Da}+\mathrm{Pr}$ \\
\hline & Radius & $\begin{array}{l}\text { Medial and distal shaft, anterior, lateral and } \\
\text { medial sides }\end{array}$ & $\mathrm{Sl} / \mathrm{Sc}$ & $\begin{array}{l}\text { Origin of m. abductor pollicis longus } \\
\text { Origin of } \mathrm{m} \text {. flexor pollicis longus }\end{array}$ & $\mathrm{Df}+\mathrm{Da}$ \\
\hline & Ulna & Medial shaft and distal end, posterior side & S1 & M. extensor pollicis longus & Da or Sk \\
\hline \multirow[t]{2}{*}{ Fore limb } & Femur & Proximal, medial and distal shaft, all sides & S1 & $\begin{array}{l}\text { M. biceps crural } \\
\text { M. gluteus maximus } \\
\text { M. vastus intermedius } \\
\text { M. vastus lateralis } \\
\text { M. vastus medialis }\end{array}$ & Df \\
\hline & Tibia & Proximal, medial and distal shaft, all sides & S1 & $\begin{array}{l}\text { M. triceps surae } \\
\text { M. tibialis anterior } \\
\text { Achilles tendon }\end{array}$ & Df/Da or Sk \\
\hline \multirow[t]{4}{*}{ Foot } & Hamate & Lateral side & S1 & Skin & Sk \\
\hline & Sesamoid & Lateral side & $\mathrm{Ch}$ & Skin & Sk \\
\hline & Metapodials & Proximal, medial and distal shaft, all sides & $\mathrm{Sl} / \mathrm{Ch}$ & $\begin{array}{l}\text { Achilles tendon } \\
\text { Tendon superficial flexor } \\
\text { Tendon interior flexor } \\
\text { Skin }\end{array}$ & Sk \\
\hline & Phalanges & $\begin{array}{l}\text { Proximal, medial and distal shaft, anterior } \\
\text { and palmar sides }\end{array}$ & S1 & Skin & Sk or Da \\
\hline
\end{tabular}

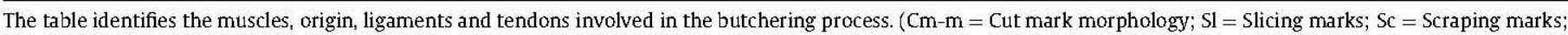
$\mathrm{Ch}=$ Chop marks; $\mathrm{Df}=$ Defleshing; $\mathrm{Sk}=$ Skinning; $\mathrm{Dm}=$ Dismembering; $\mathrm{Da}=$ Disarticulation; Ev $=\mathrm{Evisceration} ; \mathrm{Pr}=\mathrm{Periosteum}$ removal; $\mathrm{Tr}=\mathrm{Tendon}$ removal). 
base of the neural apophysis, and were made during the removal of the musculus spinalis dorsi.

Evisceration is evidenced by oblique and transversal incisions on the ventral face of the ribs. The cuts are usually on the proximal parts of the diaphysis.

In just one case, a group of incisions was found on the neck of a rib. These were produced during the dismembering of vertebrae and ribs.

The ribs of these animals, like those of $H$. antecessor, are especially affected by peeling ( $n=36$ ), and this is also seen in five vertebrae. The position of the peeling on these bones is the same as in the case of the hominin remains. The fractures occurred when dismembering the bones and possibly during their consumption (Saladié, 2009). Finally, two ribs exhibit percussion pits. We do not know the causes of these blows, as we have not been able to determine what exact part of the diaphysis they were applied to. However, it has been suggested that they may have occurred when the thorax was opened, after it had been emptied, by blows to the sternum and surrounding areas.

Hind and forelimbs The long bones of the limbs make up the set of remains most affected by cut marks ( $n=64$ ), generally oblique to the long axis of the bones. These marks are mainly consistent with defleshing activities, although dismembering and periosteum removal have also been documented.

In this sub-set, 21 humerus fragments exhibit cut marks, most of which are associated with the defleshing of the fore limb. In these cases, the incisions are mainly found in the mid-shafts, and are related to cutting the musculus brachialis and musculus deltoid. Four remains exhibit cut marks around the olecranon. Their location leaves no doubt as to their association with the separation of the humerus from the radius/ulna. In one case, scraping is associated with a percussion mark, suggesting it may have played a role in the preparation of the bone surface before it was fractured by percussion.

Eight radii fragments have cut marks generated during defleshing and four during the disarticulation of the bones. Defleshing has been identified by oblique incisions on the proximal and medial portions of the shafts. Therefore, most of the cuts are located at the origins of the musculus abductor pollicis longus and the musculus flexor pollicis longus.

In four cases, the cut marks are at the proximal and distal ends. Their location and direction (transverse and, in one case, longitudinal) has enabled us to associate these with the separation of the radius from the humerus in two cases, and the radius from the forefeet in the other two.

All of the cut marks found on the femora $(n=14)$ are related to defleshing, associated with the removal of the musculus biceps crural, gluteus maximus and vastus intermedius, lateralis and medialis. All of these marks are oblique incisions, located on different parts of the shafts, on all faces.

On the tibiae ( $n=16$ ), like on the femora, the cut marks are found along the shafts. Only in one case are the incisions located transversely on the distal metaphysis. These are associated with cutting the Achilles tendon. The other cuts are related to the consumption of the meat on the bone and the cutting of the musculus triceps surae and the tibialis anterior.

Anthropogenic breakage of the long bones has been identified by means of the presence of percussion pits in 19 remains. In all cases, the pits are located on the shafts. They are occasionally associated with the extraction of the cortex and the marrow, and adhered flakes. Three ulnae appear to exhibit peeling. In one case, this is located on the proximal part of the bone, which suggests that the fracture occurred during the separation of the radius/ulna and the humerus. In the other two cases, peeling occurs on the midshaft, leading us to believe the breakage was caused during the separation of the ulna from the radius.
Feet Eight metapodials and two medial phalanges exhibit cut marks, and a sesamoid bone should also be added to this group. In all cases, the cut marks were made while skinning the carcasses. The incisions are mainly oblique. On both the metapodials and the phalanges, the incisions are mainly on the medial and distal parts of the diaphysis. Four metapodials and a phalanx present percussion pits.

\section{Discussion}

Equifinality is an inevitable problem that arises when dealing with similar evidence caused by different actors. This extends to behavior such as cannibalism, as different types of cultural behavior may leave the same taphonomic signs. Studies in the last three decades provide a reasonably distinctive pattern of modifications associated with cannibalism (e.g., Turner II, 1983; Villa et al., 1986; White, 1992; Turner II and Turner, 1992, 1999; Boulestin, 1999; Fernández-Jalvo et al., 1999; Botella et al., 2000; Hurlbut, 2000; Cáceres et al., 2007; Saladié, 2009; Carbonell et al., 2010). Once consumption sensu stricto has been identified, the research focuses on establishing the type of cannibalism that took place and its causes. The three main types are mortuary, warfare and survival cannibalism (Kantner, 1999). Of these, only survival cannibalism does not necessarily involve any symbolic or emotional load, although it may include cultural prejudices (Rautman and Fenton, 2005). In the other two cases among anatomically modern humans, the emotional load is implicit in the act of consuming human flesh, as it is done either for the good of the deceased and their families, or as an insult to a group's enemies. The different types of cannibalism may leave behind the same or similar taphonomic evidence, but the context in which the remains are found may allow us to draw some distinctions between them.

The taphonomic data from the assemblage of level TD6 (Fernández-Jalvo et al., 1996, 1999; Rosell, 2001; Bermúdez de Castro et al., 2006; Huguet, 2007; Saladié, 2009; Carbonell et al., 2010 ) indicate that the remains resulted from nutritional cannibalism. Such cannibalism apparently formed a part of the hominins' subsistence and cultural systems, as the events took place repeatedly over a long period of dozens or possibly hundreds of years (Bermúdez de Castro et al., 2008; Saladié, 2009; Carbonell et al., 2010).

The assemblage from TD6 features the primary taphonomic characteristics that identify human cannibalism. One of the most often used forms of evidence to infer the existence of cannibalism is the similarity between the taphonomic marks on the remains of humans/hominins and those on the remains of other animals in the same assemblage (Turner II, 1983; Villa et al., 1986; White, 1992; Turner II and Turner, 1999). In the TD6 assemblage, all hominin and deer remains were processed and deposited in the same way. Cut marks are found near the origins and insertions of large muscle groups, and ligaments and tendons were cut. The neurocranial bones of both $H$. antecessor and Cervidae were skinned, and the position and characteristics of the skinning marks are similar in both cases. The skin was removed from ungulate metapodials and phalanges. These modifications can also be seen on $H$. antecessor remains, and although we can assume that the incisions cut through tendons and ligaments, the purpose of the cuts is unclear.

The signs of disarticulation, dismembering, defleshing and evisceration are greatly homogenous between the two taxonomic groups. The cut marks associated with disarticulation are located in zones with strong fibrous bands (ligaments and tendons). Defleshing has mainly left evidence on the shafts of the long bones, scapulae, os coxae, mandibles and the dorsal face of vertebrae and ribs.

Anthropogenic bone breakage is analogous in the remains of fauna and hominins. It is common in both sub-sets and has been identified through damage resulting from hammerstone 
percussion and peeling. Percussion was used mostly on the long bones and, in the case of $H$. antecessor, on skulls as well. Peeling is common on bones from the trunk and was caused in both cases during bone breakage, dismembering and possibly consumption. This technique is effectively used on more fragile bones.

The main difference in the way in which hominin and cervid remains were processed lies in the treatment of the tongue and the brain. First, tongue removal has been identified in the remains of deer but not of humans, and second, percussion marks seen on $H$. antecessor skulls suggest the removal of the brain, but such marks have not been identified on deer skulls, possibly because the remains recovered are scarce $(n=3)$.

Another difference is that $40.1 \%$ of the hominin remains exhibit some kind of modification, whereas $23.2 \%$ of the cervid remains show signs of modifications. One interpretation could be that hominin bodies were treated differently than those of other animals. No significant differences can be found between the abundance of marks on the hominin remains from TD6 and the number of human-induced modifications at other prehistoric sites in Europe. At Fontbrégoua, $46.4 \%$ of the human remains had cut marks (Villa et al., 1986), at Gough's Cave 69.3\% display some kind of anthropogenic modification (cut marks and bone breakage) (Andrews and Fernández-Jalvo, 2003), at Moula Guercy (Defleur et al., 1999) and Mirador Cave (Cáceres et al., 2007), approximately $50 \%$ of the human remains have cut marks. At all of these sites, the use of hominin flesh, marrow and brains is similar to the use documented in the TD6 remains. All of these sites feature numerous examples of anthropogenic modifications, as many or more than at TD6, which does not allow us to reach any kind of conclusion about the processing of the bodies.

The archaeological cases that have been documented show that each of the assemblages has some characteristics in common with the other sites, although some are unique, despite the expansive time range in which this behavior has been recorded. However, possible ritual traits have only been observed among anatomically modern humans, from the Upper Paleolithic onwards, for example at Gough's Cave (Andrews and Fernández-Jalvo, 2003; Bello et al., 2011), Fontbrégoua (Villa et al., 1986), Herxheim (Boulestin et al., 2009) and possibly Mirador Cave. In these cases, the cranial remains show signs of possible ritual actions. The skulls at TD6 are badly broken and scattered across the surface, and the processing of these parts seems no more or less intense than on other skeletal parts.

In short, the evidence suggests that at TD6 all taxa received similar treatment. White (1992) argues that similar processing of the carcasses may be inadequate proof of cannibalism if the context in which the hominin remains are found is not taken into account. The distribution of the remains and the amount of mixing with other taxa and archaeological material suggest a clear functional character in both cases and, in White's words (1992: 339), the objective is "nutritional benefit." However, cannibalism provides nutrients by definition and nutritional use does not necessarily exclude the possibility of other motives for the capture and consumption of the individuals recovered from TD6.

The diversity of the other known cases of cannibalism indicates that anthropophagy can have many causes. The available ethnographic and ethno-historical data show that it occurs in structured societies with great social and religious complexity (Sanday, 1986), which was not the case for Early Pleistocene hunter-gatherer groups. In addition, both endo-cannibalism and exo-cannibalism may include expressions or objectives that are not archaeologically recognizable. Archaeological remains cannot always provide answers to these questions, as some forms of behavior may not leave any material signals. The consumption of humans by other humans may connote different customs, origins and ends, generally depending on the relationship between the consumers and the consumed. This relationship may be between equals (no differences between the consumed and the consumers) or it may be a predator-prey relationship (Viláça, 2000; Fausto, 2007). In the latter case, the consumers do not recognize themselves as equal to the consumed, and therefore do not view the act as 'cannibalism'. According to Viláça (2000), the consumption of fellow beings becomes a form of predation when differences are established between consumers and the consumed. In this case, the question that should be asked is how all of the ethnographic information we possess can be extrapolated to Early Pleistocene groups, whose ontology is completely unknown, above all, considering that we know of no use of symbolic expression during that time. In the TD6 record, no material evidence has been found that would allow us to infer any kind of ritual. However, the study of the characteristics of the assemblage allows us to draw inferences about economic strategies, with which hypotheses about the ecology of the site can be proposed.

One possible explanation for the intergroup violence and cannibalism evidenced in the TD6 assemblage could be competition between two groups for resources in the same area. Signs of interpersonal violence in Pleistocene contexts have been recognized in Neanderthal remains at Saint Césaire (France) (Zollikofer et al., 2002) and Shanidar (Iraq) (Trinkaus and Zimmerman, 1982). At TD6, no traumas have been identified that can be connected with the violence and death of the hominins, although this still seems to be the most satisfactory interpretation for the assemblage. However, the age of the captured and cannibalized individuals does not correspond to cases of exo-cannibalism or intergroup human violence (Kantner, 1999), where the victims from other communities are usually adult males and sub-adult victims are less common (Hurlbut, 2000). At TD6, most of the cannibalized individuals were children at the time of death. This age profile has not been seen in other cases of prehistoric cannibalism documented in Europe (Villa et al., 1986; Boulestin, 1999; Defleur et al., 1999; Botella et al., 2000; Andrews and FernándezJalvo, 2003; Rosas et al., 2006; Cáceres et al., 2007; Boulestin et al., 2009), making it the trait that seems most divergent from other known cases of cannibalism among humans and later Pleistocene hominins. It is also somewhat different from the age profile of the animals found in the deposit, as many of these were juveniles that had reached or nearly reached their maximum size, meaning that hunting them would have involved the same risk as capturing an adult animal. Fawns are very rare. The hominin and Cervidae age profiles possibly support the involvement of different strategies or objectives in the acquisition of these taxa, and may therefore suggest the reasons and/or causes of intergroup violence and cannibalism.

The ages found among the hominins in the TD6 assemblage are more similar to those seen in cases of violence and cannibalism among chimpanzees than in other cases of Pleistocene hominins. The aggression between chimpanzee groups usually takes place during territorial boundary patrols, when the attacking group is larger than the attacked and therefore faces a lesser risk. When females with infants move alone or in small groups, they become easier targets for these attacks (Sherrow and Amsler, 2007). In these cases, the aggressors are not injured, which means the attack has a low cost (Manson and Wrangham, 1991; Wrangham, 1999; Wilson and Wrangham, 2003). The ages represented in the $H$. antecessor group at TD6 suggest that the individuals that were captured involved the least risk for the predators, which implies a low-cost territory control strategy.

These features explain the context in which the attacks occur, but not the benefits derived from them. Current evidence suggests that attacks are provoked by food defense and that the ultimate 
benefits of intergroup aggressions include an increased catchment territory along with a larger pool of mates (and fertile females) and more abundant food resources. These attacks occur at the boundaries of home areas where resources are plentiful (Mitani et al., 2010; Wilson et al., 2012). One explanation for human cannibalism is famine (survival cannibalism) and, in fact, this hypothesis is backed by references from recent history (e.g., Rautman and Fenton, 2005). However, chimpanzee behavior shows that intergroup attacks with lethal results (which include cases of cannibalism) commonly occur in times of abundant food resources.

Therefore, the possibility cannot be ruled out that cannibalism among hominins/humans also occurs in surplus contexts in response to a struggle for territory, and thus for food. Hominins would eliminate some individuals from other groups, and they would also frighten survivors away from a catchment area, just as chimpanzees appear to do with neighboring groups.

If these ideas are correct, the imbalance of power and the range expansion hypotheses may be applicable to $H$. antecessor autecology. As observed in chimpanzee behavior, both hypotheses would explain the conditions and reasons for attacks among neighboring groups whose home range or catchment areas overlapped. The high rate of infanticide documented could be explained by the fact that targeting young animals would pose the least risk for the aggressors. However, these hypotheses do not explain why the victims were consumed. In this respect, the only explanation remains nutritional benefit, in which the act of cannibalism was an act of predation, as the form of capture, consumption and abandonment of the remains suggests.

\section{Summary and conclusions}

Actualistic analogies have been used successfully to explain archaeological assemblages for several decades. In the precise case of cannibalism studies, they help to identify the act itself, and to develop theories about its causes and consequences. However, all things connected with human behavior, which is extremely flexible and variable, should be treated with great care. The cannibalism known historically and ethnographically generally took place among productive, structured and hierarchical societies, and usually involved highly complex symbolic loads. These societies usually possess complex myths, in which cannibalism is included within their concept of the world and the people who make up their societies and others. For this reason, cannibalism is generally approached within the framework of social, political or religious explanations. However, this complexity cannot be transferred directly to groups of Pleistocene foragers, for whom the practice of these customs may have been driven purely by ecological circumstances, or by a combination of many reasons, although they are not easily inferable.

Although increasing numbers of human remains with clear evidence of anthropogenic alterations and consumption have been found at prehistoric sites in Europe, this type of record is still too scarce to be able to draw general conclusions. In the case of the TD6 assemblage, the main information we possess is the following: first of all, different events of similar characteristics took place successively, and second, the processing of the remains was for nutritional purposes. Both inferences simply suggest the functional nature of the cannibalism at this site. Furthermore, we have seen that the hominins consumed were mostly immature individuals, which is clearly an indication of the consumption of the individuals involving the least risk in their capture. Aggression would have occurred in an attempt to protect the group's catchment territory, possibly from neighboring groups or from new groups in the same area. The attacked groups would probably have consisted of a few individuals, including children and adolescents, accompanied by females and/or males. Although inferences about the events leading up to the death of these individuals can be made, the cannibalism evidenced at the site can only be explained by the consumption of the bodies for nutritional reasons.

\section{Acknowledgments}

We are deeply grateful to the Atapuerca research team and the participants in the fieldwork for that project. We thank D. Begun, an anonymous associate editor, D. Watts, and an anonymous reviewer for suggestions that improved this paper. Their comments have been very useful and were essential in improving the manuscript. D. Watts has given us unpublished personal observations of great value to our conclusions. This research was supported by Ministerio de Educación y Ciencia Spanish Government Grants CGL200912703-C03-01, CGL2009-12703-C03-02, CGL2009-12703-C03-03, and CGL2009-7896, and by Generalitat de Catalunya Grant 2009 SGR 188. Funding for the fieldwork came from Consejería de Cultura y Turismo, Junta de Castilla y León and the Atapuerca Foundation. Palmira Saladié received a grant from the Duques de Soria Foundation-Atapuerca Foundation, and Rosa Huguet and Montse Esteban-Nadal received a grant from the Atapuerca Foundation. A. Rodríguez-Hidalgo is beneficiary of a predoctoral research fellowship (FPI) from the Ministry of Science and Innovation of the Spanish Government (CGL2009-12703-C03-02).

\section{References}

Andrews, P., Fernândez-Jalvo, Y., 2003. Cannibalism in Britain: taphonomy of the Creswellian (Pleistocene) faunal and human remains from Gough's (Somerset England). Bull. Nat. Hist. Mus. Geol. Ser. 58, 59-81.

Arcadi, A.C., Wrangham, R.W., 1999. Infanticide in chimpanzees: review of cases and a new within-group observation from the Kanyawara study group in Kibale National Park. Primates 40, 337-351.

Backwell, L.R., d'Errico, F., 2001. Evidence of termite foraging by Swartkrans early hominids. Proc. Natl. Acad. Sci. U S A 98, 1358-1363.

Bello, S.M., Parfitt, S.A., Stringer, C.B., 2011. Earliest directly-dated human skull-cups. Plos One 6, e17026.

Berger, G.W., Pérez-Gonzâlez, A., Carbonell, E., Arsuaga, J.L., Bermûdez de Castro, J.M., Ku, T.L., 2008. Luminescence chronology of cave sediments at the Atapuerca paleoanthropological site. Spain. J. Hum. Evol. 55, 300-311.

Bermûdez de Castro, J.M., Arsuaga, J.L., Carbonell, E., Rosas, A., Martínez, I Mosquera, M., 1997. A hominid from the lower Pleistocene of Atapuerca, Spain: possible ancestor to Neanderthals and modern humans. Science 276, 13921395.

Bermûdez de Castro, J.M., Carbonell, E., Câceres, I., Díez, J.C., Fernández-Jalvo, Y., Mosquera, M., Ollé, A., Rodríguez, J., Rodríguez, X.P., Rosas, A., Rosell, J., Sala, R., Vergés, J.M., Made, J. van der, 1999. The TD6 (Aurora stratum) hominid site. Final remarks and new questions. J. Hum. Evol. 37, 695-700.

Bermûdez de Castro, J.M., Carbonell, E., Gómez, A., Mateos, A., Martinón-Torres, M., Muela, A., Rodríguez, J., Sarmiento, S., Varela, S., 2006. Paleodemografía del hipodigma de fósiles de homininos del nivel TD6 de Gran Dolina (Sierra de Atapuerca, Burgos): estudio preliminar. Estud. Geol. 62, 145-154.

Bermûdez de Castro, J.M., Martinón-Torres, M., Prado, L., Gómez-Robles, A., Rosell, J., López-Polín, L., Arsuaga, J.L., Carbonell, E., 2010. New immature hominin fossil from European Lower Pleistocene shows the earliest evidence of a modern human dental development pattern. Proc. Natl. Acad. Sci. 102, 5674-5678.

Bermûdez de Castro, J.M., Pérez-Gonzâlez, A., Martinón-Torres, M., GómezRobles, A., Rosell, J., Prado, L., Sarmiento, S., Carbonell, E., 2008. A new early Pleistocene hominin mandible from Atapuerca-TD6, Spain. J. Hum. Evol. 55, $729-735$.

Binford, L.R., 1981. Bones: Ancient Men and Modern Myths. Academic Press, New York.

Binford, L.R, 1984. Faunal Remains from Klasies River Mouth. Academic Press, New York.

Blumenschine, R.J., Marean, C.W., Capaldo, S.D., 1996. Blind tests of inter-analyst correspondence and accuracy in the identification of cut marks, percussion marks, and carnivore tooth marks on bone surfaces. J. Archaeol. Sci. 23 493-507.

Blumenschine, R.J., Selvaggio, M.M., 1988. Percussion marks on bone surfaces as a new diagnostic of hominid behavior. Nature 333, 763-765.

Boesch, C., 1994. Hunting strategies of Gombe and Taï chimpanzees. In: Wrangham, R, McGrew, W.C., Wall, F.B., Heltne, P.G. (Eds.), Chimpanzee Cultures. Harvard University Press, Chicago, pp. 77-92.

Boesch, C., 2009. The Real Chimpanzee: Sex Strategies in the Forest. Cambridge University Press, Cambridge. 
Boesch, C., Uehara, S., Ihobe, H., 2002. Variations in chimpanzee-red colobus interactions. In: Boesch, C, Hohmann, G., Marchant, L. (Eds.), Behavioural Diversity in Chimpanzees and Bonobos. Cambridge University Press, Cambridge, pp. 221-230.

Boone, J., 1991. Comment on "intergroup aggression in chimpanzees and humans" (Manson, J.H., Wrangham, RW.). Curr. Anthropol. 32, 377

Botella, M.C., Alemán, I., Jimenez, S.A., 2000. Los Huesos Humanos. Manipulación y Alteraciones. Edicions Bellaterra, Barcelona.

Botella, M.C., Jiménez, S.A., Alemân, I., Souich, P.D., Garcia, C.J., 1997. Evidencias de canibalismo en el Neolítico Español. In: Actas del X Congreso de la Sociedad Española de Antropología Biológica. León, pp. 43-55.

Boulestin, B., 1999. Approche taphonomique des restes humaines. Le cas des mésolithiques de la grotte des Perrats et le problème du cannibalisme en Préhistoire récente Européenne. BAR Int. Ser. 776, 276.

Boulestin, B., Zeeb-Lanz, A., Jeunesse, C., Haack, F., Arbogast, RM., Denaire, A., 2009. Mass cannibalism in the linear pottery cultures at Herxheim (Palatinate, Germany). Antiquity 83, 968-982.

Burjachs, F., 2002. Paleoecología del Homo antecessor: Palinología de las unidades TD5, 6 y 7 de la 'Gran Dolina' de Atapuerca (Burgos, Spain). In: XIII Simposio de la Asociación de Palinólogos en Lengua Española (A.P.L.E.). Universidad Politécnica de Cartagena, Cartagena.

Busse, C.D., 1978. Do chimpanzees hunt cooperatively? Am. Nat. 112, 767-770.

Cáceres, I., Lozano, M., Saladié, P., 2007. Evidence for Bronze Age cannibalism in El Mirador cave (Sierra de Atapuerca, Burgos, Spain). Am. J. Phys. Anthropol. 133, 899-917.

Carbonell, E., Bermûdez de Castro, J.M., Arsuaga, J.L., Allue, E., Bastir, M., Benito, A. Cáceres, I., Canals, A., Diez, C., Made, J. van der, Mosquera, M., Ollé, A., PérezGonzâlez, A., Rodríguez, J., Rodríguez, X.P., Rosas, A., Rosell, J., Sala, R, Vallverdû, J., Vergés, J.M., 2005. An early Pleistocene hominin mandible from Atapuerca-TD6, Spain. Proc. Natl. Acad. Sci. U S A 102, 5674-5678.

Carbonell, E., Cáceres, I., Lozano, M., Saladié, P., Rosell, J., Lorenzo, C., Vallverdû, J., Huguet, R., Canals, A., Bermûdez de Castro, J.M., 2010. Cultural cannibalism as a paleoeconomic system in the European lower Pleistocene. Curr. Anthropol. 51, 539-549.

Carbonell, E., García-Antón, D., Mallol, C., Mosquera Martínez, M., ollé, A., Rodríguez, X.P., Sahnouni, M., Sala, R., Vergès, J.M., 1999. The TD6 level lithic industry from Gran Dolina, Atapuerca (Burgos, Spain): production and use. J. Hum. Evol. 37, 653-694.

Conklin, B.A., 1995. Thus are our bodies, thus was our custom: mortuary cannibalism in an Amazonian society. Am. Ethnol 2, 75-101.

Conklin, B.A., 2001. Consuming Grief: Compassionate Cannibalism in an Amazonian Society. University of Texas Press, Austin.

Cuenca-Bescós, G., Canudo, J.I., Laplana, C., 1999. Análisis bioestratigrâfico de los roedores del Pleistoceno medio del yacimiento de Galería (Sierra de Atapuerca, Burgos). In: Carbonell, E., Rosas, A., Díez, J.C. (Eds.), Atapuerca: Ocupaciones Humanas y Paleoecología del Yacimiento de Galería. Junta de Castilla y Leớn, Burgos, pp. 189-210.

Defleur, A., White, T., Valensi, P., Slimak, L., Crégut-Bonnoure, E., 1999. Neanderthal cannibalism at Moula-Guercy, Ardèche, France. Science 286, 128-131.

Domínguez-Rodrigo, M., 2002. Hunting and scavenging by early humans: the state of the debate. J. World Prehist. 16, 1-54.

Falguères, C., Bahain, J.J., Yokoyama, Y., Arsuaga, J.L., Bermûdez, J.M., Carbonell, E. Bischoff, J.L., Dolo, J.M., 1999. Earliest humans in Europe: the age of TD6 Gran Dolina, Atapuerca. Spain. J. Hum. Evol. 37, 343-352.

Fausto, C., 2007. Feasting on people eating animals and humans in Amazonia. Curr. Anthropol. 48, 497-529.

Fernández-Jalvo, Y., Díez, J.C., Bermûdez de Castro, J.M., Carbonell, E., Arsuaga, J.L, 1996. Evidence of early cannibalism. Science $271,277-278$.

Fernândez-Jalvo, Y., Díez, J.C., Câceres, I., Rosell, J., 1999. Human cannibalism in the early Pleistocene of Europe (Gran Dolina, Sierra de Atapuerca, Spain). J. Hum. Evol. 37, 591-622.

Fisher, J.W., 1995. Bone surface modifications in zooarchaeology. J. Archaeol. Method Th 2, 7-68.

Fruth, B., Hohmann, G., 2002. How bonobos handle hunts and harvest: why share food. In: Boesch, C., Hohmann, G., Marchant, L. (Eds.), Behavioural Diversity in Chimpanzees and Bonobos. Cambridge University Press, Cambridge, pp. 231-243.

García, N., 2003. Osos y Otros Carnívoros de la Sierra de Atapuerca. Fundación Oso de Asturias, Oviedo.

García, N., Arsuaga, J.L., 1999. Carnivores from the early Pleistocene hominidbearing Trinchera Dolina 6 (Sierra de Atapuerca, Spain). J. Hum. Evol. 37, $415-430$.

García, N., Arsuaga, J.L., 2001. Les carnivores (Mammalia) des sites du Pléistocène ancien et moyen d'Atapuerca (Espagne). L'Anthropologie 105, 83-93.

García-Antón, M., 1998. Reconstrucciones de paleovegetación en Atapuerca segûn el análisis polínico. In: Aguirre, E. (Ed.), Atapuerca y la Evolución Humana. Fundación Ramón Areces, Madrid, pp. 61-72.

Gilby, I.C., 2006. Meat sharing among Gombe chimpanzees: harassment and reciprocal exchange. Anim. Behav. 71, 953-963.

Gilby, I.C., Connor, R.C, 2010. The role of intelligence in group hunting: are chimpanzees different from other social predators? In: Lonsdorf, E.V., Ross, S.R. Matsuzawa, T. (Eds.), The Mind of the Chimpanzee: Ecological and Experimental Perspectives. University of Chicago Press, Chicago, pp. 220-233.

Gomes, C.M., Boesch, C., 2009. Wild chimpanzees exchange meat for sex on a longterm basis. Plos One 4, 5116 .
(1977. Infant killing and cannibalism in free-living chimpanzees. Folia Primatol. 28, 259-282.

Goodall, J., 1979. Life and death at Gombe. Natl. Geogr. 155, 592-621.

Goodall, J., 1986. The Chimpanzees of Gombe: Patterns of Behavior. Belknap Press, Cambridge.

Goldman, L., 1999. The Anthropology of Cannibalism. Praeger, Westport

Huguet, R, 2007. Primeras ocupaciones humanas en la Península Ibérica: paleoeconomía en la Sierra de Atapuerca (Burgos) y la Cuenca de Guadix-Baza (Granada) durante el Pleistoceno Inferior. Ph.D. Dissertation, Universitat Rovira i Virgili.

Hurlbut, S.A., 2000. The taphonomy of cannibalism: a review of anthropogenic bone modification in the American Southwest. Int. J. Osteoarchaeol. 10, 4-26.

Jelinek, J., 1957. Anthropofagie a pohrebni ritus doby bronzove na podklade nâlezu z moravy a zokolnich üzemi. Acta Mus, Morav. 42, 1-133.

Kantner, J., 1999. Anasazy mutilation and cannibalism in the American Southwest. In: Goldman, L.R. (Ed.), The Anthropology of Cannibalism. Bergin \& Garvey London, pp. 75-104.

Lalueza-Fox, C., Rosas, A., Estalrrich, A., Gigli, E., Campos, P.F., García-Tabernero, A., García-Vargas, S., Sânchez-Quinto, F., Ramírez, O., Civit, S., Bastir, M., Huguet, R. Santamaría, D., Thomas, M., Gilbert, P., Willerslev, E., de la Rasilla, M., 2011 Genetic evidence for patrilocal mating behavior among Neandertal groups. Proc. Natl. Acad. Sci. U S A 108, 250-253.

Lyman, R.L., 2008. Quantitative Paleozoology. Cambridge University Press, New York.

Made, J. van der, 2001. Les ongulés d'Atapuerca. Stratigraphie et biogéographie. L'Anthropologie 105, 95-113.

Manson, J.H., Wrangham, R.W., 1991. Intergroup aggression in chimpanzees and humans. Curr. Anthropol. 32, 369-390.

Mariani-Constantini, R., Ottini, L., Caramiello, S., Palmirotta, R., Mallegni, F., Rossi, A., Frati, L., Capasso, L., 2001. Taphonomy of the fossil hominid bones from the Acheulean site of Castel di Guido near Rome. Italy. J. Hum. Evol. 41, 211-225.

McCallum, C, 1996. Morte e pessoa entre os Kaxinawá. Mana 2, 19-84.

Mitani, J.C., Watts, D.P., 2001. Why do chimpanzees hunt and share meat? Anim. Behav. 61, 915-924.

Mitani, J.C., Watts, D.P., Amsler, S.J., 2010. Lethal intergroup aggression leads to territorial expansion in wild chimpanzees. Curr. Biol. 20, 507-508.

Newton-Fisher, N., 1999. Infant killers of Budongo. Folia Primatol. 70, 167-169.

Nilssen, P.J., 2000. An actualistic butchery study in South Africa and its implications for reconstructing hominid strategies of carcass acquisition and butchery in the Upper Pleistocene and Plio-Pleistocene. Ph.D. Dissertation, University of Cape Town.

Nishida, T., 1994. Review of recent findings on Mahale chimpanzees: implications and future research directions. In: Wrangham, R.W. McGrew, W.C, de Waal, F.B.M., Heltne, P.G. (Eds.), Chimpanzee Cultures. Harvard University Press, Cambridge, pp. 373-396.

Nishida, T., Kawanaka, K., 1985. Within-group cannibalism by adult male chimpanzees. Primates $26,274-284$.

Nishida, T., Uehara, S., Nyundo, R., 1979. Predatory behavior among wild chimpanzees of the Mahale Mountains. Primates 20,1-20.

Norikoshi, K., 1982. One observed case of cannibalism among wild chimpanzees of the Mahale Mountains. Primates 23, 66-74.

Parés, J.M., Pérez-Gonzâlez, A., 1995. Paleomagnetic age for hominid fossils at Atapuerca archaeological site, Spain. Science 269, 830-832.

Parés, J.M., Pérez-Gonzâlez, A., 1999. Magnetochronology and stratigraphy at Gran Dolina section, Atapuerca (Burgos, Spain). J. Hum. Evol. 37, 325-342.

Pickering, M., 1999. Consuming doubts: what some people ate? Or what some people swallowed. In: Goldman, L.R. (Ed.), The Anthropology of Cannibalism. Bergin \& Garvey, London, pp. 51-74

Pickering, T.R., Wallis, J., 1997. Bone modifications resulting from captive chimpanzee mastication: implications for the interpretation of Pliocene archaeological faunas. J. Archaeol. Sci. 24, 1115-1127.

Pickering, T.R., White, T.D., Toth, N., 2000. Cutmarks on a Plio-Pleistocene hominid from Sterkfontein, South Africa. Am. J. Phys. Anthropol. 111, 579-584.

Pobiner, B.L., Rogers, M.J., Monahan, C.M., Harris, J.W.K., 2008. New evidence for hominin carcass processing strategies at $1.5 \mathrm{Ma}$, Koobi Fora, Kenya. J. Hum. Evol 55, 103-130.

Potter, J.M., Chuipka, J.P., 2010. Perimortem mutilation of human remains in an early village in the American Southwest: a case for ethnic violence. J. Anthropol. Archaeol. 29, 507-523.

Pusey, A.E., Murray, C.M., Wallauer, W., Wilson, M., Wroblewski, E.E., 2008. Severe aggression among female chimpanzees at Gombe National Park, Tanzania. Int. J. Primatol. 29, 949-973.

Rautman, A.E., Fenton, T.W., 2005. A case of historic cannibalism in the Amer ican West: implications for southwestern archaeology. Am. Antiquity 70 $321-341$

Rodríguez, J., Burjachs, F., Cuenca-Bescós, G., García, N., Made, J., van der, PérezGonzâlez, A., Blain, H.A., Expósito, I., López-García, J.M., García-Antón, D. Allué, E., Cáceres, I., Huguet, R., Mosquera, M., Ollé, A., Rosell, J., Parés, J.M. Rodríguez, X.P., Díez, J.C., Rofes, J., Sala, R., Saladié, P., Vallverdû, J., Bennàsar, M. Blasco, R., Bermûdez de Castro, J.M., Carbonell, E., 2011. One million years of cultural evolution in a stable environment at Atapuerca (Burgos, Spain). Quatern. Sci. Rev. 30, 1396-1412.

Rosas, A., Estalrrich, A., García-Tabernero, A., Bastir, M., García Vargas, S., SánchezMeseguer, A., Huguet, R., Lallueza-Fox, C., Peña-Melián, A., Kranioti, E.F. Santamaría, D., de la Rasilla, M., Fortea, J., 2012. Les Néandertaliens d'El Sidrón 
(Asturies, Espagne). Actualisation d'un nouvel échantillon. L'Anthropologie 116 $57-76$.

Rosas, A., Martinez-Maza, C., Bastir, M., Garcia-Tabernero, A., Lalueza-Fox, C. Huguet, R, Ortiz, J.E., Julia, R., Soler, V., de Torres, T., Martinez, E., Canaveras, J.C., Sanchez-Moral, S., Cuezva, S., Lario, J., Santamaria, D., de la Rasilla, M., Fortea, J. 2006. Paleobiology and comparative morphology of a late Neandertal sample from El Sidron, Asturias, Spain. Proc. Natl Acad Sci. U S A 103, 19266-19271.

Rosell, J., 2001. Patrons d'aprofitament de les biomasses animals durant el Pleistocê Inferior i Mig (Sierra de Atapuerca, Burgos) i Superior (Abric Romaní, Barcelona). Ph.D. Dissertation, Universitat Rovira i Virgili.

Russell, M.D., 1987. Mortuary practices at the Krapina Neandertal site. Am. J. Phys. Anthropol. 72, 381-397.

Russell, M.D., LeMort, F., 1986. Cutmarks on the Engis 2 calvaria? Am. J. Phys Anthropol. 69, 317-323.

Saladié, P., 2009. Mossegades d'omnívors. Aproximació experimental i aplicació zooarqueològica als jaciments de la Sierra de Atapuerca. Ph.D. Dissertation Universitat Rovira i Virgili.

Saladié, P., Huguet, R. Díez, C., Rosell, J., Câceres, I., Rodríguez-Hidalgo, A., Vallverdû, J., Bermûdez de Castro, J.M., Carbonell, E., 2011. Carcass transport decisions in Homo antecessor subsistence strategies. J. Hum. Evol. 61, 425-446.

Sanday, P.R, 1986. Divine Hunger: Cannibalism as a Cultural System. Cambridge University Press, Cambridge.

Schiffer, M.B., 1987. Formation Processes of the Archaeological Record. University of Utah Press, Salt Lake City.

Scott, J.E., Marean, C.W., 2009. Paleolithic hominin remains from Eshkaft-e Gavi (southern Zagros Mountains, Iran): description, affinities, and evidence for butchery. J. Hum. Evol. 57, 248-259.

Sherrow, H.M., Amsler, S.J., 2007. New intercommunity infanticides by the chimpanzees of Ngogo, Kibale National Park, Uganda. Int J. Primatol. 28, 9-21.

Shipman, P., Rose, J., 1983. Early hominid hunting, butchering, and carcassprocessing behaviors: approaches to the fossil record. J. Anthropol. Archaeol. $2,57-98$.

Stanford, C.B., 1995. The influence of chimpanzee predation on group size and antipredator behaviour in red colobus monkeys. Anim. Behav. 49, 577-587.

Stanford, C.B., 1996. The hunting ecology of wild chimpanzees: implications for the evolutionary ecology of Pliocene hominids. Am. Anthropol. 98, 96-113.

Stanford, C.B., 1998. The social behavior of chimpanzees and bonobos: empirical evidence and shifting assumptions. Curr. Anthropol. 39, 399-420.

Stanford, C.B., 2001. A comparison of social meat-foraging by chimpanzees and human foragers. In: Stanford, C.B., Bunn, H. (Eds.), Meat-Eating and Human Evolution. Oxford University Press, New York, pp. 122-140.

Suzuki, A., 1971. Carnivory and cannibalism observed among forest living chimpanzees. J. Anthropol. Soc. Jpn. 79, 30-48.

Takahata, Y., 1985. Adult male chimpanzees kill and eat a male newborn infant: newly observed intragroup infanticide in Mahale Mountain National Park Tanzania. Folia Primatol. 44, 161-170.

Teleki, G., 1973. The Predatory Behavior of Wild Chimpanzees. Bucknell University Press, Lewisburg.

Trinkaus, E., 1985. Cannibalism and burial at Krapina. J. Hum. Evol. 14, 203-216.

Trinkaus, E., Zimmerman, M.R., 1982. Trauma among the Shanidar Neandertals. Am. J. Phys. Anthropol. 57, 61-67.
Turner II, C.G., 1983. Taphonomic reconstructions of human violence and cannibalism based on mass burials in the American Southwest. In: Lemoine, G.M., MacEachern, A.S. (Eds.), Carnivores, Human Scavengers, and Predators: A Question of Bone Technology. University of Calgary Archaeological Association, Calgary, pp. 219-240.

Turner II, C.G., Turner, J.A., 1992. The first claim for cannibalism in the Southwest: Walter Hough's 1901 discovery at Canyon Butte Ruin 3, Northeastern Arizona. Am. Antiquity 57, 661-682.

Turner II, C.G., Turner, J.A., 1999. Man Corn: Cannibalism and Violence in the Prehistoric American Southwest. The University of Utah Press, Salt Lake City.

Viláça, A., 2000. Relations between funerary cannibalism and warfare cannibalism: the question of predation. Ethnos 65, 83-106.

Villa, P., Bouville, C., Courtin, J., Helmer, D., Mahieu, E., Shipman, P., Belluomini, G., Branca, M., 1986. Cannibalism in the Neolithic. Science 233, 431-437.

Watts, D.P., 2008. Scavenging by chimpanzees at Ngogo and the relevance of chimpanzee scavenging to early hominin behavioral ecology. J. Hum. Evol. 54, $125-133$.

Watts, D.P., Mitani, J.C., 2000. Infanticide and cannibalism by male chimpanzees at Ngogo, Kibale National Park, Uganda. Primates 41, 357-365.

Watts, D.P., Mitani, J.C., Sherrow, H.M., 2002. New cases of inter-community infanticide by male chimpanzees at Ngogo, Kibale National Park, Uganda. Primates 43, 263-270.

Watts, D.P., Muller, M.N., Amsler, S.J., Mbabazi, G., Mitani, J.C., 2006. Lethal intergroup aggression by chimpanzees in Kibale National Park, Uganda. Am. J. Primatol. 68, 161-180.

White, T.D., 1986. Cut marks on the Bodo cranium: a case of prehistoric defleshing. Am. J. Phys. Anthropol. 69, 503-509.

White, T.D., 1992. Prehistoric Cannibalism at Mancos 5MTUMR-2346. Princeton University Press, Princeton.

White, T.D., Toth, N., 1989. Engis: preparation damage, not ancient cutmarks. Am. J. Phys. Anthropol. 78, 361-367.

White, T.D., Toth, N., 1991. The question of ritual cannibalism at Grotta Guattari. Curr. Anthropol. 32, 118-138.

Williams, J.M., Oehlert, G., Carlis, J., Pusey, A.E., 2004. Why do male chimpanzees defend a group range? Reassessing male territoriality. Anim. Behav. 68, $523-532$

Wilson, M., Kahlenberg, S.M., Wells, M., Wrangham, R.W., 2012. Ecological and social factors affect the occurrence and outcomes of intergroup encounters in chimpanzees. Anim. Behav. 83, 277-291.

Wilson, M.L., Wallauer, W.R, Pusey, A.E., 2004. New cases of intergroup violence among chimpanzees in Gombe National Park, Tanzania. Int. J. Primatol. 25, 523-549.

Wilson, M.L., Wrangham, R, 2003. Intergroup relations in chimpanzees. A. Rev. Anthropol. 32, 363-392.

Wrangham, R.W., 1999. Evolution of coalitionary killing. Yearb. Phys. Anthropol. 42, $1-30$.

Wrangham, RW., Wilson, M.L., Muller, M.N., 2006. Comparative rates of violence in chimpanzees and humans. Primates $47,14-26$.

Zollikofer, C.P.E., Ponce de León, M.S., Vandermeersch, B., Lévêque, F., 2002. Evidence for interpersonal violence in the St. Césaire Neanderthal. Proc. Natl. Acad. Sci. 99, 6444-6448. 